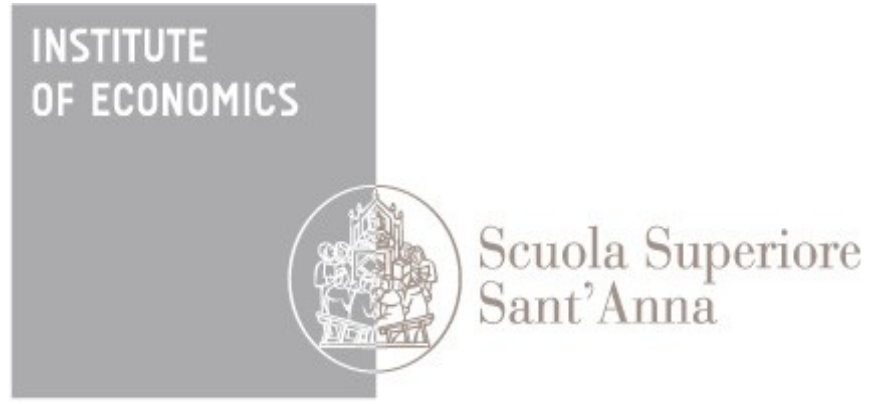

LEM | Laboratory of Economics and Management

Institute of Economics

Scuola Superiore Sant'Anna

Piazza Martiri della Libertà, 33 - 56127 Pisa, Italy ph. +3905088.33 .43$

institute.economics@sssup.it

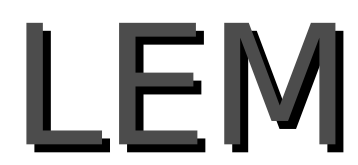

Working Paper Series

Innovation and job creation in (high-growth) new firms

Pietro Santoleri ${ }^{a, b}$

a Institute of Economics and EMbeDS Department, Scuola Superiore Sant'Anna, Pisa, Italy.

b Université Paris 1 Panthéon-Sorbonne, Paris, France. 


\title{
Innovation and job creation in (high-growth) new firms
}

\author{
Pietro Santoleri \\ Scuola Superiore Sant'Anna and EMbeDS, Pisa É Université Paris 1 Panthéon-Sorbonne, Paris
}

\begin{abstract}
Recent research has underscored the prominent role played by a small fraction of fast-growing new firms in contributing to aggregate net employment growth. While it is typically assumed that those firms experience this superior performance thanks to their ability in undertaking technological innovation, few empirical studies have explicitly addressed this issue. This article examines the innovation-employment nexus for start-ups using the Kauffman Firm Survey (KFS), a unique longitudinal dataset tracking a single cohort of US firms founded in 2004. Results based on fixed effects panel quantile regressions indicate an overall positive but heterogeneous effect of innovation activities on the conditional employment growth distribution. More in detail, the findings reveal that both research and development $(R \& D)$ and patents have a positive association with employment growth especially for those new firms experiencing high-growth.
\end{abstract}

Keywords: new firms, high-growth, innovation, employment growth, panel quantile regressions

JEL: L20, L25, M13

\footnotetext{
${ }^{1}$ p.santoleri@santannapisa.it. Acknowledgments: I would like to thank the Ewing Marion Kauffman Foundation and, in particular, Alicia Robb and Joseph Farhat for granting remote access to the confidential version of the KFS database. I am very much indebted with Daniel Lee at NORC for his precious and patient assistance with clearing the statistical output. Thanks are also due to Rajshree Agarwal, Stefano Bianchini, Alex Coad, Giovanni Dosi, Jeff Furman, Emanuele Grassi, Maria Hennicke, Keld Laursen, Andrea Mina, Mahka Moeen, Lorenzo Napolitano, Kristian Nielsen, Paul Nightingale, Gabriele Pellegrino, Fabio Pieri, Evan Rawley, Caterina Santi, João Santos Silva, Angelo Secchi, Jonathan Taglialatela, Federico Tamagni, Marco Vivarelli and the participants to the CCC Doctoral Conference (University of Pennsylvania), the Concordi conference (JRC) and the DRUID Academy (University of Southern Denmark) for insightful suggestions. I acknowledge the support of the EU Horizon 2020 research and innovation program under grant agreement No. 822781 - GROWINPRO. The usual disclaimer applies.
} 


\section{Introduction}

Throughout the last decades, a vast literature has been investigating how different innovation activities affect job creation at the firm-level. This large body of evidence suggests the presence of a 'labour-friendly' effect of innovation activities - usually proxied by R\&D and/or patents - on employment growth (Vivarelli, 2014). However, the bulk of the studies addressing such relation is based, almost exclusively, on samples of established firms whereas, mostly for lack of adequate data, there is a scarcity of research devoted to the analysis of the innovation-employment nexus for newly-born firms. This represents a crucial gap in the existing literature since new firms and, in particular, high-growth new firms contribute substantially to net aggregate job creation (Anyadike-Danes et al., 2015; Criscuolo et al., 2017; Decker et al., 2014; Haltiwanger et al., 2013).

In light of this, the article provides evidence on whether innovation activities constitute a source of differential employment growth performance for newly-born firms. To this end, the analysis exploits the Kauffman Firm Survey (KFS), a unique dataset which tracks a single cohort of US firms founded in 2004 throughout their first 8 years of activity. The dataset has several distinguished features. First, unlike previous analyses that employed datasets covering only specific industries ${ }^{1}$ or firms above a certain size threshold, the KFS is a nationally representative sample of new businesses. Second, while previous studies did not exploit panel techniques (Stam and Wennberg, 2009), our dataset allows for the use of longitudinal methods. Third, in contrast with prior research on new firms (Niefert, 2007), the KFS allows not to confine the analysis to only one indicator of innovation activities, an approach that may ignore the multifaceted nature of the innovation process (see Dosi 1988).

To evaluate the innovation-employment nexus for new firms, the empirical approach departs from the analysis of the 'average returns for the average firm' and concentrates on the effects of innovations on the whole conditional employment growth distribution. In particular, drawing on recent contributions (Bartelsman et al., 2015; Bianchini et al., 2018; Coad et al., 2016c), the study relies on fixed effects panel quantile regressions (Canay, 2011) in order to shed light on whether innovation activities are important for the performance of high-growth new firms. This represents a central contribution of the article given that, while recent evidence shows that the fastest growing new firms account for a significant share of net aggregate job creation (Haltiwanger et al., 2016), little is know on whether innovation activities drive their exceptional performance.

In line with the literature regarding incumbent firms (Coad and Rao, 2011; Vivarelli, 2014), the results show that $R \& D$ and patenting activities have an overall positive but heterogeneous effect on employment growth. Both innovation activities have a positive and increasing association with employment growth featuring the highest effect in the case of high-growth new firms, that

\footnotetext{
${ }^{1}$ This is particularly relevant because most empirical analyses are based on manufacturing firms, whereas the flow of entrants in the service sector in the US exceed manufacturing new firms around 8 to 1 (Kim et al., 2006); therefore focusing only on the latter would seriously hamper aggregate inferences in the case of new firms.
} 
is, those firms located at upper quantiles of the conditional employment growth distribution. The importance of innovative activities for fast employment growth is confirmed when using alternative innovation proxies as well as when relying on a synthetic index of new firms' innovativeness constructed using Principal Components Analysis to extract the common variance in firms' R\&D and patents.

The rest of the paper is organized as follows: Section 2 reviews relevant literature; Section 3 describes the dataset employed and provides descriptive evidence; Section 4 presents the econometric approach while Section 5 reports the estimation results; Section 6 presents the robustness analysis whereas Section 7 discusses the findings and concludes.

\section{Related literature}

This article draws upon two distinct strands of literature. First, it relates to the 'classical' debate regarding the nexus between technological change and employment. Second, it draws upon prior research dealing with entrepreneurship and high-growth new firms. The theoretical debate on the effects of innovations on employment is long-standing and, recently, has regained momentum in light of the Great Recession and the subsequent slow recovery (Calvino and Virgillito, 2018). ${ }^{2}$ One one hand, the introduction of (process) innovations might induce a decrease in employment in case they result in labour-saving productivity improvements. On the other, (product) innovations may trigger higher demand and higher market share thus counterbalancing the potential job destruction brought about by the introduction of new processes incorporated by new vintages of machinery and equipment (see Vivarelli (2014) and Calvino and Virgillito (2018) for a thorough review of the theoretical and empirical literature regarding the effects of innovation on employment).

Given the lack of theoretical consensus, recent empirical contributions have tried to shed light on this issue by exploiting the increased availability of micro data to account for the employment effects stemming from different kinds of innovation introduced at the firm level. In a nutshell, the available evidence tends to support a positive relationship among technological change and employment, particularly when $R \& D$, patents or product innovations are employed as proxies of innovation activities (Vivarelli, 2014).

Although this body of empirical literature has considerably expanded throughout the last years, almost every effort has targeted incumbent firms, often 'confined' to manufacturing or high-tech sectors. In particular, the literature which tries to dissect how innovation affects employment at

\footnotetext{
${ }^{2}$ In the US public debate, instead of being a crucial factor behind increasing living standards, technology has been depicted as responsible for the high unemployment rates. Many journalists and policymakers claim that the detrimental effect of technological change on employment creation will only increase in the future (Brynjolfsson and McAfee, 2012; Krugman, 2013). Moreover, the fear of 'technological unemployment' has been fuelled by the jobless recovery experienced by many OECD countries in the aftermath of the financial crisis although recent empirical evidence has challenged this conjecture (Graetz and Michaels, 2017). Finally, recent literature does not provide support for a negative impact of technological change on labor demand at the sectoral (Graetz and Michaels, 2018), regional (Autor et al., 2015), firm (Cortes and Salvatori, 2015) and economy-wide level (Gregory et al., 2016).
} 
the micro-level has traditionally focused on samples of i) manufacturing firms (e.g. Van Reenen, 1997), ii) service firms (e.g. Evangelista and Savona, 2003), iii) high-tech (e.g. Coad and Rao, 2008), iv) large firms (e.g. Bogliacino et al., 2012), v) small firms (e.g. Freel and Robson, 2004) and, more recently, vi) high-growth firms (e.g. Segarra and Teruel, 2014). On the contrary, and mostly for lack of adequate data, extant literature does not provide much insight in the case of new firms. Disentangling the relationship between innovation and employment growth for new firms is particularly compelling given that empirical research has shown that entrants contribute substantially to net aggregate job creation (Haltiwanger et al., 2016) as well as being more innovative and more geared towards radical forms of innovation if compared with their older counterparts (Acemoglu et al., 2013; Coad et al., 2016c; Criscuolo et al., 2012; Czarnitzki and Kraft, 2004; Hansen, 1992; Reinganum, 1983).

However, to the best of our knowledge, the only empirical contributions explicitly focusing on new firms are the ones by Stam and Wennberg (2009) and Niefert (2007). Stam and Wennberg (2009) address the effect of initial R\&D intensity (proxied by the share of total labor time dedicated to R\&D activities) on job creation for a cohort of 647 start-ups founded in the Netherlands in 1994 and which survived until 2000. Estimates obtained through ordinary least-squares suggest that R\&D intensity in the first year of activity does not affect employment growth while a positive and significant relation is found for a subset of newly founded firms in the high-tech sectors and for those start-ups experiencing high-growth. The results by Stam and Wennberg (2009) are in line with studies reporting that innovation is not necessarily beneficial to the performance and survival of new firms since it is a high-risk high-gain strategy (Boyer and Blazy, 2014; Fernandes and Paunov, 2015; Hyytinen et al., 2015): if successful, innovation might lead to high-growth performance for new firms, but there is also a high chance that they turn out to be failures and even drags on their growth rate and survival chances. The recent findings reported by Coad et al. (2016c) employing a sample of Spanish firms support the conjecture according to which R\&D activities carried out by young firms (i.e. < 10 years old) are riskier and their returns are more heterogeneous when compared to those of older firms.

Niefert (2007) provides evidence on the effects of patenting on employment growth for 1,387 German start-ups founded during the early 1990s. Results show that firms with patents applications have a positive effect on employment growth. In particular, employment growth in start-ups is affected by patenting activity over time: the effect is larger two years after patent application while no simultaneous effect is detected.

An important caveat of the existing literature regarding new firms is that the bulk of the studies base their evidence on admittedly unrepresentative samples. Indeed, the data employed generally suffer from lack of representativeness in terms of either firm age (see Coad et al. (2016c) for a discussion), firm size or sectoral coverage. ${ }^{3}$ Concerning the above-mentioned studies, Stam and

\footnotetext{
${ }^{3}$ This drawback tends to be more severe for innovation data (e.g. CIS) (Coad et al., 2016c). It also applies to
} 
Wennberg (2009) analyze only those start-ups founded in 1994 that have survived up to 2000 while Niefert (2007) does not consider firms from services such as retail trade that usually constitute a substantial share of entrants.

The article contributes to the existing literature by employing a dataset representative of the cohort of start-ups born in the US during 2004. Moreover, in contrast with Stam and Wennberg (2009), the dataset employed here allows the use of panel techniques. ${ }^{4}$ In particular, the econometric strategy relies on panel quantile regressions which also provide a more robust method to tackle the statistical properties of firm growth distributions along with accounting for firm unobserved heterogeneity. Furthermore, unlike prior research, the present study does not limit the analysis to only one indicator of innovation activities. In particular, it employs two proxies for innovation activity, namely, R\&D and the amount of patents owned by newly-born firms.

The second strand of literature is related to entrepreneurship and high-growth new firms. Based on the seminal contribution of Schumpeter (1934), the common wisdom often tends to portray entrepreneurship and innovation as similar phenomena (Colombelli et al., 2016; Stam and Wennberg, 2009). Newly-born firms are, in fact, expected to come up with and commercialize new products that disrupt the positions of incumbents and, therefore, are conceived as carriers of novelty and creative destruction. However, several contributions in the entrepreneurship literature have emphasized the overly simplistic nature of this conception and called for a more nuanced approach. Among them, Baumol (2010) highlights that innovative entrepreneurs are rather the exception while the majority is composed by 'replicative' entrepreneurs (i.e. those starting activities which are analogous to those of already-existing businesses) or 'necessity' entrepreneurs (i.e. those that embark on a business venture because they need an income). A similar conception has been put forward by Schoar (2010) who claims that the idea that entrepreneurship per se is a driver of technological change and economic prosperity is misleading since it does not take into account the heterogeneity across entrepreneurs. She argues that it is crucial to differentiate among subsistence and transformational entrepreneurs the latter group being the true engine of growth in an economy. ${ }^{5}$ In support of these views, Hurst and Pugsley (2011) show that only a small

studies addressing the innovation-survival nexus for start-ups such as Colombelli et al. (2016) who examine a sample of French start-ups operating only in the manufacturing sector and with at least 20 employees. The same can be observed for those investigations focusing on the differences in innovative behaviour of young and mature firms such as García-Quevedo et al. (2014) and Criscuolo et al. (2012) who examine firms with at least 10 employees or those analyzing whether young innovative companies grow more than other firms (Czarnitzki and Delanote, 2013). As argued by Coad (2018) "datasets that under-represent firms under the age of 10 will suffer from the distortions of sample selection bias for example, over-sampling large, profitable, innovative young firms while remaining uninformed about smaller, less successful young firms".

${ }^{4}$ The authors can only exploit the cross-sectional feature of the data because they have two data points (i.e. the years 1994 and 2000). Indeed, they argue that "[f]urther research should aim at collecting more longitudinal data in order to use panel data regression techniques" (Stam and Wennberg, 2009, p.87).

${ }^{5}$ An earlier study by Sternberg and Wennekers (2005) also stressed that different types of entrepreneurship may have a different impact on economic growth by distinguishing between opportunity versus necessity entrepreneurship. Henrekson and Sanandaji (2014) contains a useful discussion of the distinction between quantity and quality of entrepreneurship. 
share of nascent entrepreneurs in the US can be considered truly innovative. By employing the PSED dataset, these authors show that less than $20 \%$ report selling products or services that no other business provide while around $40 \%$ of new business owners declare providing similar goods or services to those of existing firms in the market.

Furthermore, they show that, although new firms are responsible for a substantial share of net aggregate employment growth, it is not true that most new businesses generate employment growth (Hurst and Pugsley, 2011; Nightingale and Coad, 2013; Shane, 2009). In fact, most new firms do not grow by any meaningful amount ${ }^{6}$ and, consistent with Haltiwanger et al. (2016), a considerable fraction of net aggregate job creation is actually due to a relatively small number of high-growth new firms. ${ }^{7}$ Based on these findings, Haltiwanger et al. (2016, p.3) argue that "high growth young firms are those that innovate and learn successfully". This consideration stems indirectly from canonical (active learning) industry dynamics models such as Ericson and Pakes (1995). But, is the performance of high-growth new firms associated with their superior capabilities in undertaking and exploiting technological innovation? Given the scarcity of empirical works, the study provides new evidence on this issue.

\section{Dataset and descriptive analysis}

\subsection{Data}

In order to conduct the analysis, the study makes use of recent longitudinal data featuring information on start-ups in the US. The Kauffman Firm Survey (KFS) is indeed a unique dataset tracking a single cohort of 3,140 US firms founded in 2004 throughout their first 8 years of life.

This dataset has several distinguished features. ${ }^{8}$ First, the KFS provides unprecedented insights into start-ups early years. Second, the KFS collects data on start-ups operating across a wide spectrum of industries, allowing generalizable results with respect to innovation and employment

\footnotetext{
${ }^{6}$ For instance, Stam and Wennberg (2009) report that most new firms (70\%) do not grow at all during over their first 6 years. In line with this, Hurst and Pugsley (2011) using the KFS show that, while about $40 \%$ of the surviving new firms hire employees, very few bring in more than one or two employees during the first 5 years of activity. More in detail, $60 \%$ of all new firms do not hire any employee, $90 \%$ added fewer than five employees, and $97 \%$ hire fewer than 10 employees. Decker et al. (2014), based on the LBD, show that the median new firm exhibits little or no growth after entry even conditional on survival.

${ }^{7}$ Shane (2009, p.145) argues that "[p]olicy makers often think that creating more start-up companies will transform depressed economic regions, generate innovation, and create jobs. This belief is flawed because the typical start-up is not innovative, creates few jobs, and generates little wealth. [...] It is about encouraging the formation of high quality, high growth companies."

${ }^{8}$ The KFS is the only longitudinal and nationally representative dataset of newly-born businesses that includes information on multiple firm-level characteristics and economic outcomes (Farhat and Robb, 2018). See Farhat et al. (2018) for a detailed review of investigations using the KFS. As reported by Zarutskie and Yang (2017, p.5) in the US "only 7 out of 26 relevant data sets for research on entrepreneurship provided longitudinal information on new venture creation, but none of the 7 data sets applied selection criteria that would lead to a representative sample of new businesses". For instance, datasets such as the Census Bureau's Longitudinal Business Database and the Bureau of Labor Statistics' Longitudinal Database do not include non-employer firms, nor do they feature data on revenues, financing or innovation activities (Zarutskie and Yang, 2017).
} 
creation for US new businesses (for a more detailed description of the KFS design and methodology see Farhat and Robb $(2018,2014))$. This is important given that start-ups in services in the US and most other advanced economies surmount manufacturing start-ups roughly 8 to 1 (Kim et al., 2006). Third, a further advantage granted by employing a sample of firms established in the same year is that it allows the examination of businesses facing the same macroeconomic conditions during their development and can, therefore, be meaningfully compared (Anyadike-Danes et al., 2015; Coad et al., 2016b; Ryder, 1965). This is especially important since recent literature has shown that macroeconomic conditions have significant effects on both firm characteristics and performance at their entry and during subsequent years (Gomis and Khatiwada, 2017; Lee and Mukoyama, 2015).

The dataset allows to tackle some of the most frequent shortcomings in investigating firm growth dynamics. On one hand, given the interest in new firm growth, we focus on 'organic' growth which corresponds to the most frequent growth followed by new businesses (Delmar et al., 2003). Consequently, those firms controlled by another firm were removed from the database, considering only those which are independent in the panel. ${ }^{9}$ On the other hand, survival bias has been regarded as a major drawback within this strand of literature (Garnsey et al., 2006). Our empirical strategy tackles this issue in two ways. First, the investigation is based on an unbalanced panel and it is not restricted to firms that have survived until the last year of the survey. Second, it relies on the probability weights available in the KFS to account both for sampling and for response bias in the baseline survey and re-constructed with each survey wave which account for the systematic failure of new businesses, and thus, their permanent exit from the data set (Farhat and Robb, 2018; Litwin and Phan, 2013). ${ }^{10}$

The KFS panel features 3,140 new firms in 2004. By the end of the time horizon covered by the survey (2011) $48 \%$ of the firms which initiated activities in 2004 has ceased operations. The cleaning procedure entailed the removal of firms with missing values and/or interrupted spells in order to have firms with at least two consecutive years for the employment variable. The loss of the first year to compute growth rates of employment, along with the presence of missing values for the innovation variables, led to a final sample of 2,124 unique firms for a total number of 10,251 observations.

\subsection{Variables and descriptive statistics}

\subsubsection{Dependent variable}

The main goal is to study the relationship between different innovation activities and employment growth. Beyond the theoretical and empirical motivations outlined in Section 2, this measure of firm performance is of high interest for policy makers, given the highly importance of job creation

\footnotetext{
${ }^{9}$ The KFS target population does not comprise new firms that were started as a branches of existing businesses or non-profit organizations.

${ }^{10}$ See the appendix for an in-depth discussion on this aspect.
} 
from a societal standpoint. Furthermore, the focus on employment growth could be particularly relevant for our analysis. Indeed, for new firms, it might be plausible that employment grows before starting generating revenues (Delmar et al., 2003). Recent empirical evidence confirms that the growth processes of firms begin with employment growth which is then followed by sales growth (Coad et al., 2016a). Furthermore, this consideration might apply particularly to new firms in high-tech sectors since they may spend years developing their products for the market (Gilbert et al., 2006) and it might take time before they start generating revenues.

Annual firm employment growth rates are computed by taking log-differences of size across two consecutive years:

$$
\text { Growth }_{i, t}=\log \left(\operatorname{Size}_{i, t}\right)-\log \left(\operatorname{Size}_{i, t-1}\right)
$$

where Size indicates the total number of employees plus one. In fact, given that a considerable number of start-ups does not have employees in their early years, in order not to discard these observations when taking logs, we add one to the original number of employees. ${ }^{11}$

Figure 1 reports the evolution of employment growth rates over time for different percentiles of the distribution. Growth rates tend to be higher in the first years (i.e. 2005-2006) while they decrease afterwards indicating that firms tend to grow less as they age. This is consistent with both empirical evidence (Coad et al., 2013; Haltiwanger et al., 2016; Navaretti et al., 2014) and theoretical models such as Jovanovic (1982) predicting young firms to experience higher and more volatile growth rates. More importantly, as shown in other empirical studies (Haltiwanger et al., 2016; Hurst and Pugsley, 2011; Stam and Wennberg, 2009), firms located around the central percentiles of the distribution experience negligible employment growth. In other words, a substantial share of new firms experiences negative or no growth whereas expansion in employment is, by no means, a common feature of new firms dynamics (Coad et al., 2016b). However, a small fraction of new firms exhibits very high rates of employment growth.

\footnotetext{
${ }^{11}$ Note that this measure considers the overall employment creation and destruction of each firm rather than the job creation and destruction within firms. For example, a firm with two employees in both 2004 and 2011 has no job creation or destruction by our measure. This is the case even if the firm had $100 \%$ employment turnover, that is, if the two employees in 2004 were different people to the two employees in 2011 . This limitation is likely to underestimate the full extent of job creation and destruction in the economy. Moreover, the distinctions between part-time vs. full-time workers or skilled labor vs. unskilled labor are not taken into account in the analysis. In this respect, Shane (2009) and Litwin and Phan (2013) highlight that jobs created in new businesses pay lower wages, grant fewer benefits and less job security than jobs in incumbent firms. On the contrary, Ouimet and Zarutskie (2014) show that young employees in new firms earn more if compared with their counterparts working in older firms. For further discussion on this point see the recent review of Block et al. (2018). Finally, an important caveat must be considered in the case of high-growth employment firms: it is important to emphasize that, while high-growth firms create a considerable amount of employment, they might disrupt other industries, displacing workers as well. Likewise, the data do not allow to take into account whether workers hired by new firms are more likely to come from outside of the labour force or from established firms as tested by Coad et al. (2017) and Astebro and Tåg (2017).
} 
Figure 1: Employment growth rates (\%) over time for different percentiles

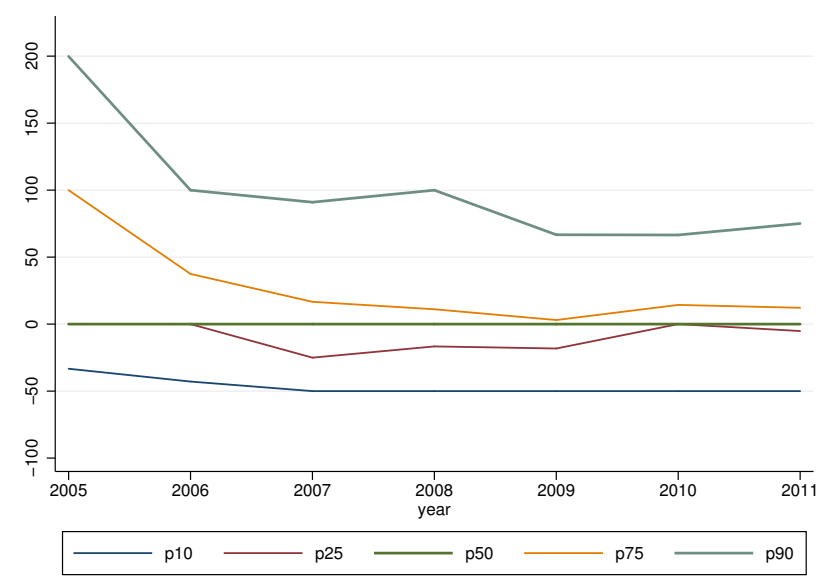

\subsubsection{Innovation proxies}

The KFS features information on a number of innovative activities carried out by the new firms during their first eight years of operations. Among them, we dispose of data concerning whether a firm is R\&D active or not. On average, roughly $18 \%$ of the firms in the sample declare to have undertaken R\&D activities. ${ }^{12}$

Additionally, the KFS contains information regarding whether new firms own some form of intellectual property (IP), namely, patents, copyrights and trademarks. In particular, in our main analysis, we use the number of patent rights owned by a firm in order to understand whether it affects employment growth. Around $3 \%$ of firms in the KFS declare to possess patents. In the following multivariate analysis, given that the distribution of patents is highly skewed, we employ the logarithmic transformation of this variable. However, an important caveat that needs to be considered when interpreting the empirical results is that the information regarding the number of patents (or the number of IP rights) is not limited to in-house generated patents but it can also comprise licensed in patents. The latter relates to those patents that are used under the authorization of the owner in exchange for an agreed payment. Hence, while patents might be conceived as the culmination of the innovative process, in our case we cannot draw such clear-cut distinction between $\mathrm{R} \& \mathrm{D}$ and patent activities as input vs output measures.

In Table 1 we report descriptive statistics regarding the growth rates of employment for the full sample as well as for new firms according to their innovation status. For both innovation proxies we observe a higher mean growth rate, however, the difference is only statistically significant for

\footnotetext{
${ }^{12}$ In robustness checks and in our exercise relying on principal component analysis, we also use a proxy of firms' innovation intensity. Drawing on previous contributions such as Shefer and Frenkel (2005) and Falk (2012), we use the ratio between $R \& D$ employees and total employees. Unfortunately, we are unable to compute a measure of R\&D spending since data regarding $R \& D$ expenditures are available only in the last three years of the sample. Finally, as for R\&D expenditures, traditional CIS-type innovation output proxies such as dummy variables related to the introduction of product or process innovation are available only in the last three waves of the KFS.
} 
R\&D firms.

Table 1: Employment growth rates by innovation status

\begin{tabular}{lccccccccc}
\hline Growth rates & $\%$ & Mean & SD & Diff. & p10 & p25 & Median & p75 & p90 \\
\hline Growth of R\&D firms & 18 & 0.084 & 0.563 & 0.007 & -0.511 & -0.065 & 0.000 & 0.336 & 0.693 \\
Growth of non-R\&D firms & 82 & 0.031 & 0.526 & - & -0.693 & -0.109 & 0.000 & 0.182 & 0.693 \\
Growth of patenting firms & 3 & 0.077 & 0.633 & 0.364 & -0.693 & -0.098 & 0.000 & 0.357 & 0.788 \\
Growth of non-patenting firms & 97 & 0.036 & 0.528 & - & -0.693 & -0.095 & 0.000 & 0.223 & 0.693 \\
\hline Total & 10,251 & 0.035 & 0.530 & - & -0.693 & -0.095 & 0.000 & 0.223 & 0.693 \\
\hline
\end{tabular}

Notes: statistics based on the pooled sample across the period 2005-2011 and obtained using probability weights. The column "Diff." contains the $p$-values of a test of equality across the mean growth rates of innovative versus non-innovative firms.

\subsubsection{Control variables}

In the subsequent regression analysis, a set of additional variables will be included to control for other potential determinants of employment growth.

As usual, one needs to control for firm size measured as the logarithm of the total number of employees plus one (Size). Although according to Gibrat's law, firm growth rates should be independent of firm size, empirical evidence has shown that smaller and younger firms have higher expected growth rates if compared with older and larger firms.

Moreover, similar to Coad et al. (2016c), we control for the possible simultaneous influence of investment in fixed assets on growth of employment. We measure investment (Inv) as the difference between total fixed assets ${ }^{13}$ over two consecutive time periods. A further simultaneous control is the number of locations ( $L O c)$ a start-up operates at. In fact, an increase in employment growth might be the result of a firm concurrently expanding its operations to an additional location.

Previous literature has extensively documented that an important obstacle to innovation and growth is access to finance (Hall and Lerner, 2010): young firms suffer from financial constraints due to the presence of considerable information asymmetries between new businesses and investors. This is particularly true in the case of start-ups engaging in risky innovative projects (Audretsch et al., 2014). Given the difficulty in measuring firms' financial constraints, recent studies have recurred to credit ratings (Bottazzi et al., 2014). Credit ratings help capital markets or financial institutions to assess the cost of external funding of a given credit rated business. As argued by Silva et al. (2012, p.20) "the main benefits from using credit ratings relate to the fact that they summarize a vast set of firms' characteristics, are firm-specific and vary over time, as well as they represent the opinion of the markets". Cole (2016), using US data, provides evidence that firms featuring lower D\&B credit ratings i) require further external financing because their credit needs have not been previously met; ii) are more discouraged from asking for further credit; iii) receive denials more frequently when applying for further credit.

\footnotetext{
${ }^{13}$ Fixed assets are deflated using the implicit price deflator (base year=2009) for private investment available from FRED
} 
Hence, to control for the availability of external funds, we employ the Dun\&Bradstreet (D\&B) Financial Stress Score provided in the KFS. ${ }^{14}$ The D\&B credit scores range from 0 to 100 (with higher scores proxying higher credit quality). Since the scores are forward-looking measures (they attempt to predict future default based on observable borrower characteristics) and are updated each year, it is the past credit score that is informative for lenders when they have to determine whether to grant credit in a given year (Bottazzi et al., 2014; Robb and Robinson, 2017). Therefore, in the regression analysis the credit scores variable (Credit) are included with one lag. ${ }^{15}$

Finally, recent empirical studies have underscored the importance of distinguishing between incorporated versus unincorporated new firms since the former are generally more growth oriented and show higher probabilities of achieving entrepreneurial success (Levine and Rubinstein, 2017), making the non-employer to employer transition (Fairlie and Miranda, 2017), experiencing extreme growth outcomes (Guzman and Stern, 2016), or becoming targets of mergers and acquisitions (Cotei and Farhat, 2017). Based on this consideration, we include a set of fixed effects controlling for the legal form declared by new firms at the time of their founding. ${ }^{16}$

Table 2 reports the description of the variables, whereas Table 3 presents weighted means and standard errors along with the pairwise correlation matrix of the covariates used in the empirical estimation. $^{17}$

Table 2: Variables description

\begin{tabular}{ll}
\hline Variables & Description \\
\hline Growth & Firm employment growth measured as $\log \left(\right.$ Size $\left._{t}\right)-\log \left(\right.$ Size $\left._{t-1}\right)$ \\
R\&D & R\&D dummy taking the value of 1 if a firm undertakes R\&D activities, and 0 otherwise \\
Pat & Number of patents owned measured as $\log ($ Patents +1$)$ \\
Size & Firm size measured as $\log ($ TotalEmployees +1$)$ \\
Inv & Investment measured as the difference in fixed assets over two consecutive time periods \\
Credit & D\&B credit scores from 0 (high-risk of financial stress) to 100 (low-risk of financial stress) \\
Location & Number of locations in which a firm operates \\
Time dummies & Dummies to control for common macroeconomic shocks and firm age-dependent factors \\
Sectoral dummies & Two-digit NAICS dummies to control for common shocks at the sectoral level \\
State dummies & State-level dummies to control for common geographical shocks \\
Legal form dummies & Dummies to control for common shocks across firm legal forms \\
\hline
\end{tabular}

\footnotetext{
${ }^{14}$ The Dun\&Bradstreet (D\&B) Financial Stress Score predicts the probability that a firm experiences financial stress during the next year. D\&B defines a financially stressed company as one that obtains legal relief from creditors, ceases operations with outstanding debts, goes into receivership or reorganization, or makes and arrangement for the benefit of creditors over the next 12 months, based on the information in D\&B's commercial database (Farhat and Robb, 2014). The KFS also contains an additional credit score (the D\&B Commercial Credit Score) that predicts the probability that a firm becomes severely delinquent in its payments over the next year (Farhat and Robb, 2014). Robustness checks using this index show similar results.

${ }^{15}$ An additional caveat of the only two studies addressing the innovation-employment nexus for start-ups (Niefert, 2007; Stam and Wennberg, 2009) is that they only partially control for financial factors affecting innovative activities.

${ }^{16}$ The forms of organization are Sole Proprietorship, Limited Liability Company, Subchapter S-Corporation, CCorporation, General Partnership, and Limited Partnership.

${ }^{17}$ Notwithstanding the low correlations, we also checked the degree of multi-collinearity by means of variance inflation factors (VIF). The mean VIF was 1.04. Hence, given this relatively low value, multi-collinearity does not appear to be a major issue for our analysis.
} 
Table 3: Summary statistics and pair-wise correlation matrix

\begin{tabular}{|c|c|c|c|c|c|c|c|c|c|c|}
\hline Variables & Mean & $\mathrm{SD}$ & Median & Growth & $\mathrm{R} \& \mathrm{D}_{t-1}$ & $\mathrm{Pat}_{t-1}$ & Size $_{t-1}$ & $\operatorname{Inv} t$ & Credit $_{t-1}$ & $\operatorname{Loc}_{t}$ \\
\hline Growth $_{t}$ & 0.04 & 0.51 & 0.00 & 1.000 & & & & & & \\
\hline $\mathrm{R} \& \mathrm{D}_{t-1}$ & 0.18 & - & 0.00 & $\begin{array}{c}0.086 \\
(0.000)\end{array}$ & 1.000 & & & & & \\
\hline $\mathrm{Pat}_{t-1}$ & 0.03 & - & 0.00 & $\begin{array}{l}0.0020 \\
(0.881)\end{array}$ & $\begin{array}{c}0.126 \\
(0.000)\end{array}$ & 1.000 & & & & \\
\hline Size $_{t-1}$ & 6.22 & 13.12 & 3.00 & $\begin{array}{l}-0.106 \\
(0.000)\end{array}$ & $\begin{array}{l}-0.266 \\
(0.000)\end{array}$ & $\begin{array}{c}0.129 \\
(0.000)\end{array}$ & 1.000 & & & \\
\hline $\operatorname{Inv} t$ & 0.02 & 0.70 & 0.02 & $\begin{array}{c}0.053 \\
(0.000)\end{array}$ & $\begin{array}{l}-0.015 \\
(0.256)\end{array}$ & $\begin{array}{l}-0.021 \\
(0.117)\end{array}$ & $\begin{array}{c}0.004 \\
(0.762)\end{array}$ & 1.000 & & \\
\hline Credit $_{t-1}$ & 43.50 & 23.73 & 41.00 & $\begin{array}{c}0.075 \\
(0.000)\end{array}$ & $\begin{array}{l}-0.044 \\
(0.000)\end{array}$ & $\begin{array}{l}0.0101 \\
(0.457)\end{array}$ & $\begin{array}{c}0.088 \\
(0.000)\end{array}$ & $\begin{array}{c}0.013 \\
(0.337)\end{array}$ & 1.000 & \\
\hline Location $_{t}$ & 1.22 & 1.07 & 1.00 & $\begin{array}{c}0.049 \\
(0.000)\end{array}$ & $\begin{array}{l}-0.009 \\
(0.482)\end{array}$ & $\begin{array}{c}0.076 \\
(0.000)\end{array}$ & $\begin{array}{c}0.117 \\
(0.000)\end{array}$ & $\begin{array}{c}0.025 \\
(0.061)\end{array}$ & $\begin{array}{l}-0.003 \\
(0.826)\end{array}$ & 1.000 \\
\hline
\end{tabular}

Notes: pair-wise correlations based on the pooled estimation sample. Mean, median and standard deviations of all explanatory variables are computed before the logarithmic transformation. $p$-values in parenthesis. We do not present minimum and maximum values for confidentiality reasons.

\section{Econometric approach}

The primary objective of the analysis relates to the estimation of the effects of $R \& D$ and patents on employment growth. The econometric procedure takes stock of previous contributions in the industrial dynamics literature concerned with the innovation-growth nexus at the firm-level. In particular, the empirical framework needs to consider the heavy-tail property of firm growth rates distributions (Bottazzi and Secchi, 2006) along with the highly skewed returns to innovation (Coad and Rao, 2008, 2011). To address both concerns, previous studies have adopted quantile regressions techniques (Koenker and Bassett Jr, 1978) given that they are robust to the presence of outliers in the dependent variable and allow for the estimation of the innovation effects at different percentiles of the conditional employment growth distribution. This approach is particularly suited for our analysis because we are also interested in examining whether $R \& D$ and patenting activities are associated with high-growth employment performance in start-ups, given their crucial role for the overall dynamism of the economy (Haltiwanger et al., 2016).

While most efforts at disentangling the effects of innovation activities on firm growth applied cross-sectional quantile regressions, the present study follows an ensemble of recent empirical analyses (Bartelsman et al., 2015; Bianchini et al., 2018; Coad et al., 2016c; Di Cintio et al., 2017) that have exploited new developments in quantile regression methods. In particular, they resort to the estimator introduced by Canay (2011) that takes advantage of panel data features and allows to control for firm unobserved heterogeneity. This represents an important aspect given that not all the determinants of firm growth can be observed. Indeed, estimating models which do not account for this aspect as in previous works (Stam and Wennberg, 2009) might produce biased estimates whereas the unobserved effects are correlated with observed explanatory variables in the 
model. ${ }^{18}$ The method employed here, accounting for unobserved constant firm effects, represents a way to alleviate this problem. In particular, we rely on the estimation procedure presented in Canay (2011). To better illustrate it, let us start from the following equation:

$$
y_{i, t}=x_{i, t}^{\prime} \beta+u_{i}+\epsilon_{i, t}
$$

where $y_{i, t}$ represents the dependent variable (in our case employment growth) and $x_{i, t}^{\prime}$ is a vector of independent variables (encompassing the innovation proxies in our models). The method entails a first step in which one estimates Eq. (1) by means of the standard within estimator in order to compute firm unobserved heterogeneity, $u_{i, t}$. Once $\hat{u}_{i}$ is obtained it is assumed to be 'location shifter', that is, it takes the same value across the different quantiles. Successively, the second step requires the estimation of a standard quantile regression (Koenker and Bassett Jr, 1978) on the new dependent variable $\left(\hat{y}_{i, t}\right)$ depurated from the unobserved heterogeneity component $\left(\hat{y}_{i, t}=y_{i, t}-\hat{u}_{i}\right) .{ }^{19}$ Bootstrapping techniques are generally used to ensure proper inference when estimating quantile regressions. However, given that standard bootstrapping is not appropriate when employing complex survey designs, we follow the bootstrap method developed by Kolenikov et al. (2010) which is suitable for complex survey data.

In order to shed light on whether innovative activities affect the conditional employment growth distribution in the case of new firms, we estimate augmented Gibrat's type equations using the above mentioned two-step procedure. ${ }^{20}$ They read as follows:

$$
\begin{array}{r}
\text { Frowth }_{i, t}=\alpha_{1}+\beta_{1} \text { Inn }_{i, t-1}+\beta_{2} \text { Growth }_{i, t-1}+\beta_{3} \text { Size }_{i, t-1}+\beta_{4} \text { Inv }_{i, t} \\
+\beta_{5} \text { Credit }_{i, t-1}+\beta_{6} \text { Loc }_{i, t}+\lambda_{t}+\phi_{s}+\kappa_{l}+\eta_{r}+u_{i}+\epsilon_{i, t}
\end{array}
$$

where Growt $_{i, t}$ is employment growth for firm $i$ at time $t$, while Inn indicates, alternatively, $\mathrm{R} \& \mathrm{D}$ or the number of patents, which represent our innovation proxies. They are inserted with one lag to reduce potential simultaneity bias and given that it is often found that innovation activities affect firm growth with a certain time lag (Falk, 2012; Van Roy et al., 2018). Additionally, our models include lagged growth rates to control for auto-correlation of growth rates. However, for both innovation and lagged growth rates variables, we do not explore further lags since this would

\footnotetext{
${ }^{18}$ In more detail, innovative new firms might be endowed with particular strategic capabilities or behavioural features allowing them to adopt and generate new technology more easily with respect to other new firms. If employment growth is driven by such unobserved factors, then the effect of innovation activities will be overestimated (Niefert, 2007).

${ }^{19}$ See Canay (2011) for further details on the estimation method. Note that this estimator is consistent and asymptotically normal as both $T$ and $N$ grow. In particular, based on Monte Carlo simulations, Canay (2011) shows that when $T$ approaches 10, the bias is low irrespective of the value of $N$ and that the estimator performs as well as the Koenker (2004) estimator. Finally, note that alternative approaches to panel quantile regressions such as Graham et al. (2015) are not feasible given that they do not accommodate the use of probability weights.

${ }^{20}$ See Falk (2012) and Coad (2018) for similar specifications.
} 
lead to a substantial loss of observations given the unbalanced nature of the panel. Additional controls encompass firm size and credit ratings lagged one period whereas investment and location variables are inserted simultaneously.

Moreover, to account for the considerable heterogeneity characterizing new firms (Hurst and Pugsley, 2011) we include a full set of fixed effects in all specifications. $u_{i}$ corresponds to timeinvariant firm-specific effects. $\phi_{s}$ is a sector-specific effect, which is taken into account by including two-digit NAICS sector dummies. $\lambda_{t}$ is a time-specific effect, accounted for by including time dummies capturing business cycle effects as well as age-related factors. $\eta_{r}$ captures region-specific effects by including State-level dummies. $\kappa_{l}$ control for legal form-specific factors by including dummies indicating different forms of organization declared by new businesses at the time of founding while $\epsilon_{i, t}$ represents the standard error term.

Although the above specifications control for firm-level characteristics as well as for potential confounding time-invariant firm-specific effects and allow for time lags of the innovation proxies with respect to the dependent variable to mitigate simultaneity bias, the empirical strategy does not address all possible sources of endogeneity. Indeed, the estimation results might be subject to reverse causality given that innovative firms might grow more but it might well be the case that firms enjoying higher growth rates could devote more resources to future innovation activities. In light of this, the estimates presented successively must be interpreted as associations and not causal effects.

\section{Empirical results}

Tables 4 and 5 present the regression results from Eq. (2) whereas Figure 2 provides a graphical representation of the parameters obtained for the innovation proxies. Estimates are reported for nine different percentiles, from the 10th to the 90th. Quantile regression coefficients can be interpreted as the marginal change in the dependent variable of the conditional quantile caused by marginal change in a particular regressor. The results show that $R \& D$ has an overall positive effect on employment growth. In particular, the coefficients are statistically significant for all firms located at or above the 30th percentile indicating that the effects of R\&D differ across the conditional employment growth distribution. Indeed, the coefficients feature a monotonic trend from the 10th to the upper quantiles of the distribution whereas they are statistically significant at the $1 \%$ level only starting from the 50 th percentile. In other words, undertaking R\&D appears to matter only for those firms that have achieved a certain level of employment growth. This finding is in line with earlier empirical evidence concerning incumbent firms (Coad and Rao, 2011; Falk, 2012).

Furthermore, consistent with the results of Stam and Wennberg (2009) on Dutch start-ups, $\mathrm{R} \& \mathrm{D}$ appears to be of particular relevance for high-growth firms (i.e. those located at the 90th percentile). However, contrarily to what shown by Coad et al. (2016c), we do not find R\&D to be 
a drag for employment growth for those firms located at lowest quantiles of the distribution. ${ }^{21}$

Table 4: R\&D and employment growth

\begin{tabular}{|c|c|c|c|c|c|c|c|c|c|}
\hline & \multicolumn{9}{|c|}{ Fixed effects quantile regressions } \\
\hline & $\mathrm{p} 10$ & $\mathrm{p} 20$ & p30 & $\mathrm{p} 40$ & $\mathrm{p} 50$ & p60 & p70 & $\mathrm{p} 80$ & p90 \\
\hline $\mathrm{R} \& \mathrm{D}_{t-1}$ & $\begin{array}{c}0.019 \\
(0.028)\end{array}$ & $\begin{array}{c}0.020 \\
(0.018)\end{array}$ & $\begin{array}{c}0.030^{* *} \\
(0.013)\end{array}$ & $\begin{array}{c}0.022^{* *} \\
(0.010)\end{array}$ & $\begin{array}{c}0.027^{* * *} \\
(0.008)\end{array}$ & $\begin{array}{c}0.027^{* * *} \\
(0.009)\end{array}$ & $\begin{array}{c}0.033^{* *} \\
(0.016)\end{array}$ & $\begin{array}{c}0.064^{* * *} \\
(0.021)\end{array}$ & $\begin{array}{c}0.082^{* * *} \\
(0.029)\end{array}$ \\
\hline Growth $_{t-1}$ & $\begin{array}{c}0.010 \\
(0.017)\end{array}$ & $\begin{array}{l}-0.003 \\
(0.015)\end{array}$ & $\begin{array}{c}0.003 \\
(0.014)\end{array}$ & $\begin{array}{c}0.007 \\
(0.010)\end{array}$ & $\begin{array}{c}0.001 \\
(0.009)\end{array}$ & $\begin{array}{l}-0.004 \\
(0.010)\end{array}$ & $\begin{array}{l}-0.007 \\
(0.012)\end{array}$ & $\begin{array}{l}-0.016 \\
(0.016)\end{array}$ & $\begin{array}{c}0.011 \\
(0.019)\end{array}$ \\
\hline $\operatorname{Inv}_{t}$ & $\begin{array}{c}0.016^{* * *} \\
(0.004)\end{array}$ & $\begin{array}{c}0.011^{* * *} \\
(0.003)\end{array}$ & $\begin{array}{l}0.005^{*} \\
(0.003)\end{array}$ & $\begin{array}{c}0.004^{* *} \\
(0.002)\end{array}$ & $\begin{array}{l}0.002^{*} \\
(0.001)\end{array}$ & $\begin{array}{c}0.001 \\
(0.001)\end{array}$ & $\begin{array}{c}0.003 \\
(0.002)\end{array}$ & $\begin{array}{c}0.001 \\
(0.004)\end{array}$ & $\begin{array}{l}-0.001 \\
(0.004)\end{array}$ \\
\hline Credit $_{t-1}$ & $\begin{array}{c}0.002^{* * *} \\
(0.000)\end{array}$ & $\begin{array}{c}0.002^{* * *} \\
(0.000)\end{array}$ & $\begin{array}{c}0.001^{* * *} \\
(0.000)\end{array}$ & $\begin{array}{c}0.001^{* * *} \\
(0.000)\end{array}$ & $\begin{array}{c}0.001^{* * *} \\
(0.000)\end{array}$ & $\begin{array}{c}0.001^{* * *} \\
(0.000)\end{array}$ & $\begin{array}{c}0.001^{* * *} \\
(0.000)\end{array}$ & $\begin{array}{c}0.001^{* * *} \\
(0.000)\end{array}$ & $\begin{array}{c}0.001^{* *} \\
(0.000)\end{array}$ \\
\hline $\operatorname{Size}_{t-1}$ & $\begin{array}{c}-0.927^{* * *} \\
(0.012)\end{array}$ & $\begin{array}{c}-0.926^{* * *} \\
(0.007)\end{array}$ & $\begin{array}{c}-0.927^{* * *} \\
(0.006)\end{array}$ & $\begin{array}{c}-0.929^{* * *} \\
(0.005)\end{array}$ & $\begin{array}{c}-0.920^{* * *} \\
(0.004)\end{array}$ & $\begin{array}{c}-0.907^{* * *} \\
(0.005)\end{array}$ & $\begin{array}{c}-0.897^{* * *} \\
(0.007)\end{array}$ & $\begin{array}{c}-0.922^{* * *} \\
(0.010)\end{array}$ & $\begin{array}{c}-0.973^{* * *} \\
(0.013)\end{array}$ \\
\hline Location $_{t}$ & $\begin{array}{c}0.003 \\
(0.003)\end{array}$ & $\begin{array}{c}0.002 \\
(0.003)\end{array}$ & $\begin{array}{c}0.002 \\
(0.002)\end{array}$ & $\begin{array}{c}0.001 \\
(0.002)\end{array}$ & $\begin{array}{c}0.001 \\
(0.002)\end{array}$ & $\begin{array}{c}0.001 \\
(0.002)\end{array}$ & $\begin{array}{c}0.002 \\
(0.002)\end{array}$ & $\begin{array}{c}0.000 \\
(0.001)\end{array}$ & $\begin{array}{c}-0.000 \\
(0.003)\end{array}$ \\
\hline Constant & $\begin{array}{c}0.689^{* * *} \\
(0.094)\end{array}$ & $\begin{array}{c}0.750^{* * *} \\
(0.063)\end{array}$ & $\begin{array}{c}0.838^{* * *} \\
(0.061)\end{array}$ & $\begin{array}{c}0.851^{* * *} \\
(0.082)\end{array}$ & $\begin{array}{c}0.905^{* * *} \\
(0.157)\end{array}$ & $\begin{array}{c}0.902^{* * *} \\
(0.194)\end{array}$ & $\begin{array}{c}1.056^{* * *} \\
(0.298)\end{array}$ & $\begin{array}{c}1.163^{* * *} \\
(0.333)\end{array}$ & $\begin{array}{c}1.789^{* * *} \\
(0.312)\end{array}$ \\
\hline Firm FE & Yes & Yes & Yes & Yes & Yes & Yes & Yes & Yes & Yes \\
\hline State FE & Yes & Yes & Yes & Yes & Yes & Yes & Yes & Yes & Yes \\
\hline Sector FE & Yes & Yes & Yes & Yes & Yes & Yes & Yes & Yes & Yes \\
\hline Time FE & Yes & Yes & Yes & Yes & Yes & Yes & Yes & Yes & Yes \\
\hline Legal f. FE & Yes & Yes & Yes & Yes & Yes & Yes & Yes & Yes & Yes \\
\hline$N$ & 8127 & 8127 & 8127 & 8127 & 8127 & 8127 & 8127 & 8127 & 8127 \\
\hline Pseudo $R^{2}$ & 0.679 & 0.684 & 0.687 & 0.688 & 0.686 & 0.675 & 0.654 & 0.616 & 0.560 \\
\hline
\end{tabular}

Notes: Fixed Effects QR (Canay, 2011) estimates using KFS survey weights. Bootstrapped standard errors (100 iterations) based on Kolenikov et al. (2010) are in parenthesis. Time (6), sector (21), State (52) and legal forms (6) dummies are included but not reported for the sake of brevity. ${ }^{*} p<0.10,{ }^{* *} p<0.05,{ }^{* * *} p<0.01$.

We now focus our analysis on the employment effects derived from owning patents. The results in Table 5 indicate that the lagged amount of patents is positively and significantly associated (at the $1 \%$ level) with employment growth starting from those firms at the 30th percentile. Similar to the results regarding $\mathrm{R} \& \mathrm{D}$, we observe that the effect of patents generally increases across quantiles with coefficients featuring the largest magnitude for firms located at the 90th percentile. Even in this case the results underscore the importance of innovation activities for high-growth performance.

These results are consistent with Niefert (2007) findings indicating that patenting activities do influence positively the employment growth rates of the average German new firm. Moreover, they are in line with recent research highlighting the relevance of patents and intellectual property rights in the case of high-growth firms (BERR, 2008; Helmers et al., 2013), start-ups (Farre-Mensa et al., 2017) and start-ups featuring extremely positive growth outcomes (Guzman and Stern, 2016).

To sum up, both innovation proxies have a positive (although heterogeneous) effect on employment growth. In particular, $R \& D$ has a positive and statistically significant association with employment growth for all firms located at or above the 30th percentile of the conditional distribution. Similarly, the association between patents and employment growth is positive and significant

\footnotetext{
${ }^{21}$ Note that these findings hold also when employing a R\&D intensity measure (see Table 11 in the Appendix).
} 
Table 5: Patents and employment growth

\begin{tabular}{|c|c|c|c|c|c|c|c|c|c|}
\hline & \multicolumn{9}{|c|}{ Fixed effects quantile regressions } \\
\hline & p10 & p20 & p30 & $\mathrm{p} 40$ & $\mathrm{p} 50$ & $\mathrm{p} 60$ & p70 & $\mathrm{p} 80$ & p90 \\
\hline $\mathrm{Pat}_{t-1}$ & $\begin{array}{l}0.044^{*} \\
(0.026)\end{array}$ & $\begin{array}{c}0.039 \\
(0.025)\end{array}$ & $\begin{array}{c}0.062^{* * *} \\
(0.019)\end{array}$ & $\begin{array}{c}0.055^{* * *} \\
(0.017)\end{array}$ & $\begin{array}{c}0.063^{* * *} \\
(0.023)\end{array}$ & $\begin{array}{c}0.078^{* * *} \\
(0.024)\end{array}$ & $\begin{array}{c}0.086^{* * *} \\
(0.027)\end{array}$ & $\begin{array}{c}0.107^{* * *} \\
(0.033)\end{array}$ & $\begin{array}{c}0.122^{* * * *} \\
(0.034)\end{array}$ \\
\hline Growth $_{t-1}$ & $\begin{array}{c}0.008 \\
(0.018)\end{array}$ & $\begin{array}{l}-0.010 \\
(0.015)\end{array}$ & $\begin{array}{c}0.003 \\
(0.015)\end{array}$ & $\begin{array}{c}0.006 \\
(0.009)\end{array}$ & $\begin{array}{l}-0.001 \\
(0.009)\end{array}$ & $\begin{array}{l}-0.004 \\
(0.011)\end{array}$ & $\begin{array}{c}-0.009 \\
(0.013)\end{array}$ & $\begin{array}{l}-0.016 \\
(0.017)\end{array}$ & $\begin{array}{c}0.011 \\
(0.019)\end{array}$ \\
\hline $\operatorname{Inv}_{t}$ & $\begin{array}{c}0.016^{* * *} \\
(0.004)\end{array}$ & $\begin{array}{c}0.009^{* * *} \\
(0.003)\end{array}$ & $\begin{array}{c}0.004 \\
(0.003)\end{array}$ & $\begin{array}{c}0.004^{* *} \\
(0.002)\end{array}$ & $\begin{array}{c}0.002 \\
(0.001)\end{array}$ & $\begin{array}{c}0.000 \\
(0.001)\end{array}$ & $\begin{array}{c}0.003 \\
(0.002)\end{array}$ & $\begin{array}{c}0.002 \\
(0.004)\end{array}$ & $\begin{array}{l}-0.001 \\
(0.005)\end{array}$ \\
\hline Credit $_{t-1}$ & $\begin{array}{c}0.002^{* * *} \\
(0.000)\end{array}$ & $\begin{array}{c}0.001^{* * *} \\
(0.000)\end{array}$ & $\begin{array}{c}0.001^{* * *} \\
(0.000)\end{array}$ & $\begin{array}{c}0.001^{* * *} \\
(0.000)\end{array}$ & $\begin{array}{c}0.001^{* * *} \\
(0.000)\end{array}$ & $\begin{array}{c}0.001^{* * *} \\
(0.000)\end{array}$ & $\begin{array}{c}0.001^{* * *} \\
(0.000)\end{array}$ & $\begin{array}{c}0.001^{* * *} \\
(0.000)\end{array}$ & $\begin{array}{c}0.001^{* * *} \\
(0.000)\end{array}$ \\
\hline $\operatorname{Size}_{t-1}$ & $\begin{array}{c}-0.925^{* * *} \\
(0.012)\end{array}$ & $\begin{array}{c}-0.925^{* * *} \\
(0.007)\end{array}$ & $\begin{array}{c}-0.925^{* * *} \\
(0.006)\end{array}$ & $\begin{array}{c}-0.929^{* * *} \\
(0.004)\end{array}$ & $\begin{array}{c}-0.919^{* * *} \\
(0.004)\end{array}$ & $\begin{array}{c}-0.907^{* * *} \\
(0.004)\end{array}$ & $\begin{array}{c}-0.895^{* * *} \\
(0.007)\end{array}$ & $\begin{array}{c}-0.920^{* * *} \\
(0.010)\end{array}$ & $\begin{array}{c}-0.972^{* * *} \\
(0.013)\end{array}$ \\
\hline Location $_{t}$ & $\begin{array}{c}0.003 \\
(0.003)\end{array}$ & $\begin{array}{c}0.002 \\
(0.003)\end{array}$ & $\begin{array}{c}0.002 \\
(0.002)\end{array}$ & $\begin{array}{c}0.001 \\
(0.002)\end{array}$ & $\begin{array}{c}0.001 \\
(0.002)\end{array}$ & $\begin{array}{c}0.001 \\
(0.002)\end{array}$ & $\begin{array}{c}0.002 \\
(0.002)\end{array}$ & $\begin{array}{c}0.000 \\
(0.001)\end{array}$ & $\begin{array}{c}-0.000 \\
(0.003)\end{array}$ \\
\hline Constant & $\begin{array}{c}0.706^{* * *} \\
(0.102)\end{array}$ & $\begin{array}{c}0.776^{* * *} \\
(0.061)\end{array}$ & $\begin{array}{c}0.846^{* * *} \\
(0.055)\end{array}$ & $\begin{array}{c}0.817^{* * *} \\
(0.077)\end{array}$ & $\begin{array}{c}0.906^{* * *} \\
(0.161)\end{array}$ & $\begin{array}{c}0.901^{* * *} \\
(0.192)\end{array}$ & $\begin{array}{c}1.029^{* * *} \\
(0.302)\end{array}$ & $\begin{array}{c}1.150^{* * *} \\
(0.340)\end{array}$ & $\begin{array}{c}1.804^{* * *} \\
(0.320)\end{array}$ \\
\hline Firm FE & Yes & Yes & Yes & Yes & Yes & Yes & Yes & Yes & Yes \\
\hline State FE & Yes & Yes & Yes & Yes & Yes & Yes & Yes & Yes & Yes \\
\hline Sector FE & Yes & Yes & Yes & Yes & Yes & Yes & Yes & Yes & Yes \\
\hline Time FE & Yes & Yes & Yes & Yes & Yes & Yes & Yes & Yes & Yes \\
\hline Legal f. FE & Yes & Yes & Yes & Yes & Yes & Yes & Yes & Yes & Yes \\
\hline$N$ & 8127 & 8127 & 8127 & 8127 & 8127 & 8127 & 8127 & 8127 & 8127 \\
\hline Pseudo $R^{2}$ & 0.679 & 0.685 & 0.688 & 0.689 & 0.687 & 0.676 & 0.655 & 0.616 & 0.559 \\
\hline
\end{tabular}

Notes: Fixed Effects QR (Canay, 2011) estimates using KFS survey weights. Bootstrapped standard errors (100 iterations) based on Kolenikov et al. (2010) are in parenthesis. Time (6), sector (21), State (52) and legal forms (6) dummies are included but not reported for the sake of brevity. ${ }^{*} p<0.10,{ }^{* *} p<0.05,{ }^{* * *} p<0.01$.

Figure 2: The effects of innovation on employment growth

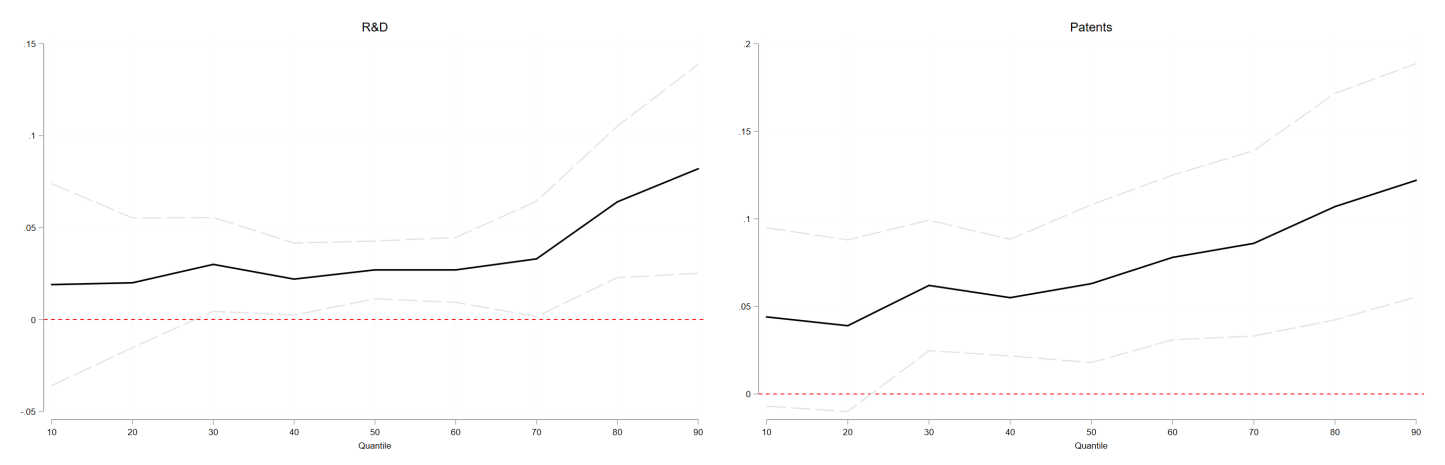

Notes: the figures plot the point estimates of R\&D (left panel) and patents (right panel) across quantiles. Dashed lines represent respective $95 \%$ confidence bands. 
starting from the 30th percentile with a particularly large effect detected for high-growth new firms. Note that including both innovation proxies in the same equation does not lead to any noticeable change in the point estimates and patterns of statistical significance (see Table 6 in the Appendix).

Finally, it is worth highlighting the results for the remaining variables in the models and, in particular, on the coefficients of firm size and lagged growth rates. As for Gibrat's Law, the coefficients are negative and strongly statistically significant. The magnitude of the point estimates indicate a rejection of the Gibrat's Law meaning that there seems to be convergence in the growth process of larger and smaller firms. ${ }^{22}$ This is in line with Lotti et al. (2009) who show that Gibrat's Law is rejected in the case of young and small firms while it holds in the long run, once learning and market selection have fully played their roles.

Focusing on the auto-correlation of growth rates, we find that the estimated parameters are generally not statistically significant. In unreported analysis we rerun our models including only lagged size and lagged growth rates as independent variables and found that, if anything, autocorrelation of growth rates is positive especially until the fourth year of operation. This is in line with recent empirical investigations showing that, in the case of young firms, auto-correlation of growth rates is positive in their first years of activity (Coad et al., 2018, 2013). In particular, Coad et al. (2018, p.3) argue that "young firms are characterized by positive growth auto-correlation in the years immediately after entry, but that the auto-correlation coefficient quickly turns negative, and remains negative as firms get older. Nascent ventures, therefore, enjoy a brief spell of positive growth persistence a sort of 'success-breeds-success' dynamic which lasts for fewer than five years, until persistence becomes negative".

Concerning the other control variables inserted in the models, coefficients of credit ratings are generally statistically significant and present the expected signs. These feature the strongest impact at lower quantiles indicating that an increase in credit ratings (proxying external credit worthiness) triggers higher growth rates especially for those firms experiencing declining growth rates of employment. The estimates of the location variable, on the contrary, do not seem to exert any statistically significant effect. Lastly, point estimates for investment in fixed assets tend to be positive and statistically significant only for firms in the lower percentiles of the conditional employment growth distribution. ${ }^{23}$

\footnotetext{
${ }^{22}$ As argued by Coad (2018), the large magnitude of the estimated parameters might be related to the first-step fixed-effects regression. To obtain a clearer picture, we run models inserting exclusively Size $_{i, t-1}$ as independent variable (along with time, sector and State level dummies) using OLS, FE and GMM-sys. The estimates clearly reject Gibrat's law for the whole sample of firms since the coefficient is negative and statistically significant with magnitudes generally closer to zero if compared with the ones reported in the main analysis. We also run FE estimations using alternatively two consecutive years of data and regressing current employment growth against lagged size along with the usual controls. The $S i z e_{i, t}$ coefficient is always negative and statistically significant thus providing additional

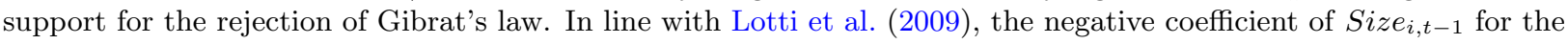
first two years (2005-2006) is the largest while the ones from the following years gradually tend to zero.

${ }^{23}$ In unreported analysis, we alternatively included the growth of investment obtaining similar results.
} 


\section{Extensions and robustness}

This section presents a series of additional exercises along with robustness checks to test the sensitivity of the estimation results presented so far.

Innovativeness index and employment growth in new firms. The estimation results presented so far, in line with studies focusing on incumbents (Coad and Rao, 2011; Vivarelli, 2014), tend to confirm the overall positive (and heterogeneous) effects of innovation activities on employment growth even in the case of new firms. However, as widely discussed in the literature, R\&D and patents are imperfect proxies of firm-level innovativeness. To provide additional evidence on the importance of innovation for new firms' employment growth, we rely on principal components analysis (PCA). This technique has been previously adopted in empirical works investigating the effects of R\&D and patents on employment growth (Buerger et al., 2012; Coad and Rao, 2011). Indeed, although $R \& D$ and patents shed light on different aspects of the innovation process, they are only partial proxies of firm-level innovation activities (Griliches, 1990; Kleinknecht et al., 2002). The intrinsically multifaceted nature of such phenomena suggests the combination of various individual indicators (Kleinknecht et al., 2002). Therefore, we employ PCA to extract the common variance between R\&D and patent variables (both scaled by the total amount of employees of each firm) while discarding their idiosyncratic variance that includes noise, measurement error, and specific variation. By doing so we obtain a synthetic index of new firms innovativeness.

Table 7 reports the results of the PCA analysis. The eigenvalues represents the variances of the principal components. The first principal component (INN1) has variance 1.10, explaining $55 \%$ of the total variance. The second principal component (INN2) has variance 0.90 or $45 \%$ of the total variance.

Therefore, we retain the principal component INN1 and insert it in our model with one lag. Given that the point estimates for the synthetic index do not have a straightforward interpretation, we are interested in its qualitative effects over the conditional employment growth distribution. The estimation results presented in Table 8 largely support the findings previously showed by separately investigating the effects of R\&D dummy and that of patents. In fact, the lagged synthetic index $\left(I N N_{t-1}\right)$ shows a monotonic relation along the conditional employment growth distribution (with statistically significant point estimates at the $1 \%$ level starting from the 30 th percentile) and present the highest coefficient for the fastest growing firms.

Models without lagged dependent variable. We rerun the main equations to explore whether the exclusion of the lagged dependent variable affected the estimates. ${ }^{24}$ As one might expect, in some cases point estimates of the innovation variables tend to show larger magnitudes and present higher statistical significance. Nevertheless, on qualitative grounds results do not show any noticeable change (see Tables 9 and 10).

\footnotetext{
${ }^{24}$ Note that in this specification we do not insert the location variable (Loc) since this is available only from the 3rd wave of the KFS.
} 
Alternative innovation proxies. To test the sensitivity of the results presented in the previous sections, we rerun our main specifications employing alternative innovation proxies. More in detail, we replace the $R \& D$ dummy with a continuous variable capturing $R \& D$ intensity measured as the ratio between $R \& D$ employees over total employment. Likewise, we replaced the patent variable with a broader proxy of intellectual property rights considering not only patents but also copyrights and trademarks. Overall we observe similar findings for both proxies (see Tables 11 and 12 in the Appendix). Furthermore, in order to test the sensitivity of the estimation results obtained using the synthetic index, we performed the PCA by including the R\&D variable along with the number of copyrights, trademarks and patents separately (as opposed to the total amount of patents). The results using this principal component show no noticeable changes (see Table 13 in the Appendix).

Additional control variables. The baseline specifications were augmented employing a set of industry-level variables such as sales growth, minimum efficient scale and the Herfindahl index. These variables show limited explanatory power and do not qualitatively alter the results previously showed. Furthermore, our results are inevitably affected by the Great Recession and, since we examine only one cohort of firms, it is an arduous task to properly disentangle the impact of the crisis from age-dependent factors (Zarutskie and Yang, 2017). In order to test the sensitivity of our estimates to the crisis, we run alternative specifications including a full set of year-industry (at one-digit NAICS level) fixed effects. ${ }^{25}$ The estimates of the innovation proxies are qualitatively similar to the ones reported in the main analysis. ${ }^{26}$

Cross-sectional quantile regressions. As previously discussed, the Canay (2011) estimator employed for our main estimates is consistent and asymptotically normal as $T$ grows. In order to check the results obtained by means of fixed effects panel quantile regressions, we re-run all equations employing the traditional cross-sectional quantile regression estimator (Koenker and Bassett Jr, 1978). The estimation results confirm that both $R \& D$ and patents have a positive effect on employment growth. However, differently from the estimates obtained via the Canay (2011) method, when estimating this alternative specification the positive (and statistically significant) effects are limited to the upper quantiles (from the 70th to the 90th) of the conditional employment growth distribution (see Tables 14 and 15 in the Appendix). Although such results deliver a less optimistic picture (no statistically significant effect is detected for those firms located at lower percentiles), the cross-sectional quantile regressions provide additional evidence on the heterogeneous nature of innovation returns and on the importance of innovation activities for the performance of highgrowth new firms. Finally, given that cross-sectional quantile regressions do not allow to control for firm-specific unobserved factors, we also augmented the baseline regressions with a large set of time-invariant regressors capturing multiple firm- and owner-level characteristics. The results confirm the positive and statistically significant relation between the innovation proxies and em-

\footnotetext{
${ }^{25}$ Including year-sector (at two-digit NAICS level) fixed effects renders computationally infeasible the estimation of bootstrapped standard errors given the limited sample size.

${ }^{26}$ Details on the results of these additional tests are available upon request.
} 
ployment growth in new firms especially for those located in the upper part of the conditional distribution (results are available upon request).

\section{Conclusions}

\subsection{Key findings and discussion}

The main purpose of the study is to contribute to the surprisingly scant empirical evidence regarding the innovation-employment nexus for newly-born firms. In order to do so, it is based on data for a cohort of US start-ups founded in 2004 and tracked until 2011. Unlike the few existing studies that have only exploited the cross-sectional features of the data (Stam and Wennberg, 2009), with a limited sectoral coverage (Niefert, 2007) or based on samples which admittedly under-represent young firms (Coad et al., 2016c; Criscuolo et al., 2012), the present analysis takes advantage of a longitudinal representative sample of independent new firms. Moreover, the paper provides a broad picture on the effect of new firm innovativeness and employment growth by using different proxies for innovation activities. Furthermore, it is not confined to the analysis of the 'average returns for the average firm' rather it focuses on how innovations affect the whole conditional employment growth distribution and, in particular, the performance of high-growth new firms.

In agreement with the literature investigating the innovation-employment nexus for incumbents (Vivarelli, 2014), the results point towards the existence of a 'labour-friendly' effect of innovation on employment creation. Moreover, they confirm previous works showing that innovation returns are highly heterogeneous across the conditional employment growth distribution (Coad and Rao, 2011; Falk, 2012). Shrinking firms do not generally benefit from innovation activities. On the contrary, the findings concerning the fastest growing firms indicate that the innovation proxies are significantly and positively associated with their performance. This result might be interpreted as supporting the idea, recently put forward by Shane (2009), Hurst and Pugsley (2011) and Colombelli et al. (2016), according to which entrepreneurship is not important per se: it is a small subset of highly innovative new firms that foster aggregate economic dynamism. More importantly, this paper is among the few studies providing evidence in support of the notion that innovativeness is a relevant factor shaping the performance of these economic agents which significantly contribute to aggregate job creation (Haltiwanger et al., 2016).

Although with caution, our estimates could be interpreted based on the recent literature. In fact, Coad et al. (2016c) by employing Spanish data find that an increase in the R\&D intensity by young firms might lead to substantial losses given its intrinsic uncertainty. Furthermore, results from Stam and Wennberg (2009) show that, for the average start-up in the Netherlands, initial $\mathrm{R} \& \mathrm{D}$ does not translate into higher employment growth. Based on these results, one might argue that our estimates provide support for the idea that US entrants are more capable in translating $\mathrm{R} \& \mathrm{D}$ efforts into employment gains. Also, additional evidence in this direction is given by the 
lack of a negative and statistically significant association between R\&D intensity and subsequent employment growth - as reported in Coad et al. (2016c) - and by that, although with some degree of heterogeneity, being innovative seems to be an important factor for enhancing employment growth of US start-ups. This is in line with recent evidence showing that young leading innovators in the EU display a lower R\&D intensity if compared with their US counterparts (Cincera and Veugelers, 2013) and that American young firms yield substantially higher rates of return to R\&D vis-á-vis older businesses, while this does not happen for European young innovative companies (Cincera and Veugelers, 2014).

The estimates presented are also in line with Niefert (2007) who finds that patenting activities do affect positively the employment growth rates of the average German new firm. Moreover, they are consistent with recent research highlighting the relevance of patents and intellectual property rights in the case of high-growth firms (BERR, 2008; Helmers et al., 2013), start-ups (Farre-Mensa et al., 2017) and start-ups featuring extremely positive growth outcomes (Guzman and Stern, 2016).

Lastly, the results might cast doubts on policies aimed at supporting any kind of new firms stemming from the conjecture that, the higher the number of entrants, the higher the amount of businesses that will succeed and boost job creation (Colombelli et al., 2016; Shane, 2009). However, this view neglects the huge heterogeneity characterizing entrants (Hurst and Pugsley, 2011) in terms of both their innovative and growth potential. In contrast with this approach, the empirical analysis presented here supports the recent policy shift from stimulating the entry and survival of all kinds of new firms to fostering the entry and survival of innovative new firms. ${ }^{27}$

\subsection{Limitations and future research}

The above findings, however, must be interpreted considering the limitations characterizing this study. First, as already pointed out, the econometric strategy does not intend to address all potential sources of endogeneity and, hence, the estimates presented should be interpreted as associations and not causal effects. Furthermore, while previous literature has not regarded omitted variable bias as particularly problematic for firm growth analyses - given that studies have struggled to find any specific observable factor explaining growth variation to large extents (Coad, 2009) - the impossibility in the present context of accounting for the role of growth orientation might represent a relevant shortcoming. In fact, growth orientation has been shown to mediate the relationship between innovation and new firm growth (McKelvie et al., 2017). The inclusion of legal form fixed effects in the regression analysis is motivated precisely by the fact that recent evidence shows that incorporated firms tend to have better growth motivations and prospects if compared with unincorporated businesses (Guzman and Stern, 2016). However, future research

\footnotetext{
${ }^{27}$ A long-standing example of such policies is the US Small Business Innovation Research (SBIR), whereas more recent ones are the Start-Up Chile, the Finnish NIY Programme (Autio and Rannikko, 2016), the Italian Start-up Act (Menon et al., 2018) or the EU SME instrument (i.e. the European version of the US SBIR).
} 
should more systematically address the interplay between growth motivations, innovation activities and employment creation in new firms.

Second, innovation is a complex phenomenon whose measurement is a daunting task. Empirical studies often recur to imperfect and partial proxies and this analysis represents no exception. Beyond the widely discussed pitfalls of measures such as R\&D and patenting activities, one has to take into account that these innovation proxies are more suited for older and larger firms and may poorly depict innovative efforts carried out by new firms. In particular, R\&D activities may not accurately capture the (less resource-demanding) innovation carried out by start-ups since this is often informally organized. Hence, this might lead to an underestimation of R\&D efforts in new firms (Ortega-Argilés et al., 2009). A further limitation concerns the patent (or intellectual property) variable employed in our analysis. Start-ups, in fact, may generate innovations that are not easy to protect formally or may decide not to recur to formal intellectual property given the high costs entailed. Future investigations should provide evidence employing informal intellectual property mechanisms since they have been shown to be used as complementary appropriation strategy by young, innovative businesses (Veugelers and Schneider, 2017). Moreover, we do not have information on which is the share of patents (or intellectual property) that is internally generated or externally acquired. This is a relevant caveat given that, while internally generated patents might be more associated with product innovation, the licensing in of externally generated patents might actually be more linked to innovative input and, hence, process innovation. Therefore, their effect on employment might differ substantially between the two. Recent empirical evidence has also shown that young firms substantially rely on embodied technical change from external sources (Pellegrino et al., 2012; Protogerou et al., 2017). Future research should address more in detail the importance of internal vs external sources of technical change for the growth performance of newly-established firms.

Third, given the nature of our dataset, we limit our analysis to the effects of one-year lagged innovation activities on employment growth. However, one must take into account that the returns to innovation might materialize over a longer time period than the one considered here. For instance, Niefert (2007) documents that the effects of patents on employment growth is stronger after two years. Future studies targeting new firms should shed more light concerning this aspect.

Fourth, in order to test the conjecture outlined in the previous subsection regarding the higher capacity for US entrants to benefit from R\&D efforts if compared with their European counterparts, future investigations might exploit both the KFS and the KfW/ZEW Start-up Panel which features information on German start-ups during their first years of activity.

Fifth, given the absence of proxies related to process innovation in the KFS, future research should disentangle the impact of these innovation outputs on employment growth, their complementarity and the potential compensation mechanisms.

Finally, as recently advocated in other studies (Coad, 2018; Criscuolo et al., 2012), future studies should devote more efforts in disentangling the effects of radical vs incremental innovation 
on firm growth dynamics of new firms as well as tackling potential differences across sectors. ${ }^{28}$

\section{References}

Acemoglu, D., Akcigit, U., Bloom, N., Kerr, W. R., 2013. Innovation, reallocation and growth. NBER Working Paper No. 18993.

URL http://dx.doi.org/10.3386/w18993

Anyadike-Danes, M., Bjuggren, C.-M., Gottschalk, S., Hölzl, W., Johansson, D., Maliranta, M., Myrann, A., 2015. An international cohort comparison of size effects on job growth. Small Business Economics 44 (4), 821-844. URL http://dx.doi.org/10.1007/s11187-014-9622-0

Astebro, T. B., Tåg, J., 2017. Gross, net, and new job creation by entrepreneurs. Journal of Business Venturing Insights.

Audretsch, D. B., Segarra, A., Teruel, M., 2014. Why don’t all young firms invest in R\&D? Small Business Economics 43 (4), 751-766.

URL http://dx.doi.org/10.1007/s11187-014-9561-9

Autio, E., Rannikko, H., 2016. Retaining winners: Can policy boost high-growth entrepreneurship? Research policy $45(1), 42-55$.

Autor, D., Dorn, D., Hanson, G. H., 2015. Untangling trade and technology: Evidence from local labour markets. The Economic Journal 125 (584), 621-646.

URL http://dx.doi.org/10.1111/ecoj.12245

Bartelsman, E., Dobbelaere, S., Peters, B., 2015. Allocation of human capital and innovation at the frontier: firm-level evidence on Germany and the Netherlands. Industrial and Corporate Change 24 (5), 875-949.

Baumol, W. J., 2010. The microtheory of innovative entrepreneurship. Princeton University Press.

BERR, 2008. High-growth firms in the United Kingdom: Lessons from an analysis of comparative UK performance. Department for Business Enterprise \& Regulatory Reform, BERR Economics Paper 3.

Bianchini, S., Pellegrino, G., Tamagni, F., 2018. Innovation complementarities and firm growth. Industrial and Corporate Change 27 (4), 657-676.

URL http://dx.doi.org/10.1093/icc/dty008

Block, J. H., Fisch, C. O., Van Praag, M., 2018. Quantity and quality of jobs by entrepreneurial firms. Oxford Review of Economic Policy 34 (4), 565-583.

Bogliacino, F., Piva, M., Vivarelli, M., 2012. R\&D and employment: An application of the LSDVC estimator using European microdata. Economics Letters 116 (1), 56-59.

URL http://doi.org/10.1016/j.econlet.2012.01.010

Bottazzi, G., Secchi, A., 2006. Explaining the distribution of firm growth rates. The RAND Journal of Economics 37 (2), 235-256.

URL http://dx.doi.org/10.1111/j.1756-2171.2006.tb00014.x

Bottazzi, G., Secchi, A., Tamagni, F., 2014. Financial constraints and firm dynamics. Small Business Economics $42(1), 99-116$.

URL http://dx.doi.org/10.1007/s11187-012-9465-5

Boyer, T., Blazy, R., 2014. Born to be alive? The survival of innovative and non-innovative French micro-start-ups. Small Business Economics 42 (4), 669-683.

\footnotetext{
${ }^{28}$ In the present study we restrain from conducting sectoral estimations. In fact, when carrying out subpopulation analysis within the context of complex survey design, to properly compute the variance of an estimate for a subpopulation one should take the randomness in the subpopulation sample size into account by including all the data in the regression (see Farhat and Robb (2018) for further details). Unfortunately, the Stata commands employed for the present analysis do not support the use of the routines necessary to conduct subpopulation analysis.
} 
Brynjolfsson, E., McAfee, A., 2012. Race against the machine: How the digital revolution is accelerating innovation, driving productivity, and irreversibly transforming employment and the economy. Brynjolfsson and McAfee.

Buerger, M., Broekel, T., Coad, A., 2012. Regional dynamics of innovation: Investigating the co-evolution of patents, research and development (R\&D), and employment. Regional Studies 46 (5), 565-582.

URL http://dx.doi.org/10.1080/00343404.2010.520693

Calvino, F., Virgillito, M. E., 2018. The innovation-employment nexus: A critical survey of theory and empirics. Journal of Economic Surveys 32 (1), 83-117.

Canay, I. A., 2011. A simple approach to quantile regression for panel data. The Econometrics Journal 14 (3), $368-$ 386.

URL http://dx.doi.org/10.1111/j.1368-423X.2011.00349.x

Cincera, M., Veugelers, R., 2013. Young leading innovators and the EU's R\&D intensity gap. Economics of Innovation and New Technology 22 (2), 177-198.

URL http://dx.doi.org/10.1080/10438599.2012.731166

Cincera, M., Veugelers, R., 2014. Differences in the rates of return to R\&D for European and US young leading R\&D firms. Research policy 43 (8), 1413-1421.

URL http://doi.org/10.1016/j.respol.2014.03.004

Coad, A., 2009. The growth of firms: A survey of theories and empirical evidence. Edward Elgar Publishing.

Coad, A., 2018. Firm age: A survey. Journal of Evolutionary Economics 28 (1), 13-43.

Coad, A., Cowling, M., Siepel, J., 2016a. Growth processes of high-growth firms as a four-dimensional chicken and egg. Industrial and Corporate Change 26 (4), 537-554.

Coad, A., Daunfeldt, S.-O., Halvarsson, D., Jan 2018. Bursting into life: Firm growth and growth persistence by age. Small Business Economics 50 (1), 55-75.

URL https://doi.org/10.1007/s11187-017-9872-8

Coad, A., Frankish, J. S., Roberts, R. G., Storey, D. J., 2016b. Predicting new venture survival and growth: Does the fog lift? Small Business Economics 47 (1), 217-241.

Coad, A., Nielsen, K., Timmermans, B., 2017. My first employee: An empirical investigation. Small Business Economics 48 (1), 25-45.

Coad, A., Rao, R., 2008. Innovation and firm growth in high-tech sectors: A quantile regression approach. Research policy 37 (4), 633-648.

URL http://doi.org/10.1016/j.respol.2008.01.003

Coad, A., Rao, R., 2011. The firm-level employment effects of innovations in high-tech US manufacturing industries. Journal of Evolutionary Economics 21 (2), 255-283.

URL http://dx.doi.org/10.1007/s00191-010-0209-x

Coad, A., Segarra, A., Teruel, M., 2013. Like milk or wine: Does firm performance improve with age? Structural Change and Economic Dynamics 24, 173-189.

URL http://doi.org/10.1016/j.strueco.2012.07.002

Coad, A., Segarra, A., Teruel, M., 2016c. Innovation and firm growth: Does firm age play a role? Research Policy $45(2), 387-400$

Cochran, W. G., 1977. Sampling techniques. New York: John Wiley and Sons.

Cole, R. A., 2016. Credit scores and credit market outcomes: Evidence from the SSBF and KFS. US Small Business Administration Research Paper (419).

Colombelli, A., Krafft, J., Vivarelli, M., 2016. To be born is not enough: The key role of innovative start-ups. Small Business Economics, 1-15.

URL http://dx.doi.org/10.1007/s11187-016-9716-y

Cortes, G. M., Salvatori, A., 2015. Task specialization within establishments and the decline of routine employment. Tech. rep., working paper, University of Manchester. 
URL https://www.frbatlanta.org/ /media/Documents/research/seminars/2016/cortes-011916.pdf

Cotei, C., Farhat, J., 2017. The M\&A exit outcomes of new, young firms. Small Business Economics, 1-23.

Criscuolo, C., Gal, P. N., Menon, C., 2017. Do micro start-ups fuel job creation? Cross-country evidence from the DynEmp Express database. Small Business Economics 48 (2), 393-412.

Criscuolo, P., Nicolaou, N., Salter, A., 2012. The elixir (or burden) of youth? exploring differences in innovation between start-ups and established firms. Research Policy 41 (2), 319-333.

Czarnitzki, D., Delanote, J., 2013. Young innovative companies: The new high-growth firms? Industrial and Corporate Change 22 (5), 1315-1340.

Czarnitzki, D., Kraft, K., 2004. An empirical test of the asymmetric models on innovative activity: who invests more into R\&D, the incumbent or the challenger? Journal of Economic Behavior \& Organization 54 (2), 153-173.

Decker, R., Haltiwanger, J., Jarmin, R., Miranda, J., 2014. The role of entrepreneurship in US job creation and economic dynamism. The Journal of Economic Perspectives 28 (3), 3-24.

URL http://www . aeaweb.org/articles?id=10.1257/jep.28.3.3

Delmar, F., Davidsson, P., Gartner, W. B., 2003. Arriving at the high-growth firm. Journal of business venturing 18 (2), 189-216.

URL http://doi.org/10.1016/S0883-9026(02)00080-0

Di Cintio, M., Ghosh, S., Grassi, E., 2017. Firm growth, R\&D expenditures and exports: an empirical analysis of italian SMEs. Research Policy 46 (4), 836-852.

Dosi, G., 1988. Sources, procedures, and microeconomic effects of innovation. Journal of economic literature, 11201171.

Ericson, R., Pakes, A., 1995. Markov-perfect industry dynamics: A framework for empirical work. The Review of Economic Studies 62 (1), 53-82.

URL http://www.jstor.org/stable/2297841

Evangelista, R., Savona, M., 2003. Innovation, employment and skills in services. firm and sectoral evidence. Structural Change and Economic Dynamics 14 (4), 449-474.

URL http://doi.org/10.1016/S0954-349X (03)00030-4

Fairlie, R. W., Miranda, J., 2017. Taking the leap: The determinants of entrepreneurs hiring their first employee. Journal of Economics \& Management Strategy 26 (1), 3-34.

Falk, M., 2012. Quantile estimates of the impact of R\&D intensity on firm performance. Small Business Economics 39 (1), 19-37.

URL http://dx.doi.org/10.1007/s11187-010-9290-7

Farhat, J., Matusik, S., Robb, A., Robinson, D. T., 2018. New directions in entrepreneurship research with the Kauffman Firm Survey. Small Business Economics 50 (3), 521-532.

Farhat, J., Robb, A., 2018. Analyzing complex survey data: the Kauffman Firm Survey. Small Business Economics 50 (3), 657-670.

Farhat, J. B., Robb, A., 2014. Applied Survey Data Analysis Using Stata: The Kauffman Firm Survey Data. Available at SSRN 2477217.

Farre-Mensa, J., Hegde, D., Ljungqvist, A., 2017. What is a Patent Worth? Evidence from the US Patent "Lottery" . Tech. rep., National Bureau of Economic Research.

Fernandes, A. M., Paunov, C., 2015. The risks of innovation: Are innovating firms less likely to die? Review of Economics and Statistics 97 (3), 638-653.

Freel, M. S., Robson, P. J., 2004. Small firm innovation, growth and performance: Evidence from Scotland and Northern England. International Small Business Journal 22 (6), 561-575.

URL http://dx.doi.org/10.1177/0266242604047410

García-Quevedo, J., Pellegrino, G., Vivarelli, M., 2014. R\&D drivers and age: Are young firms different? Research Policy 43 (9), 1544-1556. 
URL http://doi.org/10.1016/j.respol.2014.04.003

Garnsey, E., Stam, E., Heffernan, P., 2006. New firm growth: exploring processes and paths. Industry and Innovation 13 (1), 1-20.

URL http://dx.doi.org/10.1080/13662710500513367

Gilbert, B. A., McDougall, P. P., Audretsch, D. B., 2006. New venture growth: A review and extension. Journal of management 32 (6), 926-950.

Gomis, R. M., Khatiwada, S., 2017. Firm dynamics and business cycle: What doesn't kill you makes you stronger? Tech. rep., Economics Section, The Graduate Institute of International Studies.

Graetz, G., Michaels, G., 2017. Is modern technology responsible for jobless recoveries? American Economic Review 107 (5), 168-73.

Graetz, G., Michaels, G., 2018. Robots at work. The Review of Economics and Statistics 100 (5), 753-768. URL https://doi.org/10.1162/rest_a_00754

Graham, B. S., Hahn, J., Poirier, A., Powell, J. L., 2015. Quantile regression with panel data. Tech. rep., National Bureau of Economic Research.

Gregory, T., Salomons, A., Zierahn, U., 2016. Racing with or against the machine? Evidence from Europe. URL http://ftp.zew.de/pub/zew-docs/dp/dp16053.pdf

Griliches, Z., 1990. Patent statistics as economic indicators: A survey. Tech. rep., National Bureau of Economic Research.

Guzman, J., Stern, S., 2016. Nowcasting and placecasting entrepreneurial quality and performance. In: Measuring Entrepreneurial Businesses: Current Knowledge and Challenges. University of Chicago Press.

URL http://www.nber.org/chapters/c13493.pdf

Hall, B. H., Lerner, J., 2010. The financing of R\&D and innovation. Handbook of the Economics of Innovation 1, 609-639.

Haltiwanger, J., Jarmin, R. S., Kulick, R., Miranda, J., et al., 2016. High growth young firms: Contribution to job, output, and productivity growth. NBER Chapters, 11-62.

URL http://www.nber.org/chapters/c13492

Haltiwanger, J., Jarmin, R. S., Miranda, J., 2013. Who creates jobs? Small versus large versus young. Review of Economics and Statistics 95 (2), 347-361.

Hansen, J. A., 1992. Innovation, firm size, and firm age. Small Business Economics 4 (1), 37-44. URL http://dx.doi.org/10.1007/BF00402214

Heckman, J. J., 1977. Sample selection bias as a specification error (with an application to the estimation of labor supply functions). Tech. rep., National Bureau of Economic Research.

Helmers, C., von Graevenitz, G., Greenhalgh, C., Guceri, I., Schautschick, P., 2013. Intellectual property rights and high-growth firms in the UK. UK Intellectual Property Office Report 27.

Henrekson, M., Sanandaji, T., 2014. Small business activity does not measure entrepreneurship. Proceedings of the National Academy of Sciences 111 (5), 1760-1765.

Hurst, E., Pugsley, B., 2011. What do small businesses do [with comments and discussion]. Brookings Papers on Economic Activity, 73-142.

URL http://www.jstor.org/stable/41473598

Hyytinen, A., Pajarinen, M., Rouvinen, P., 2015. Does innovativeness reduce startup survival rates? Journal of Business Venturing 30 (4), 564-581.

Jovanovic, B., 1982. Selection and the evolution of industry. Econometrica: Journal of the Econometric Society, 649-670.

URL http://www.jstor.org/stable/1912606

Kim, P. H., Aldrich, H. E., Keister, L. A., 2006. Access (not) denied: The impact of financial, human, and cultural capital on entrepreneurial entry in the united states. Small Business Economics 27 (1), 5-22. 
URL http://dx.doi.org/10.1007/s11187-006-0007-x

Kleinknecht, A., Van Montfort, K., Brouwer, E., 2002. The non-trivial choice between innovation indicators. Economics of Innovation and new technology 11 (2), 109-121.

Koenker, R., 2004. Quantile regression for longitudinal data. Journal of Multivariate Analysis 91 (1), 74-89.

Koenker, R., Bassett Jr, G., 1978. Regression quantiles. Econometrica: journal of the Econometric Society, 33-50.

Kolenikov, S., et al., 2010. Resampling variance estimation for complex survey data. Stata Journal 10 (2), $165-199$.

Krugman, P., 2013. Sympathy for the luddites. New York Times 13.

Lee, Y., Mukoyama, T., 2015. Entry and exit of manufacturing plants over the business cycle. European Economic Review 77, 20-27.

Levine, R., Rubinstein, Y., 2017. Smart and illicit: Who becomes an entrepreneur and do they earn more? The Quarterly Journal of Economics 132 (2), 963-1018.

Litwin, A. S., Phan, P. H., 2013. Quality over quantity: Reexamining the link between entrepreneurship and job creation. Industrial \& Labor Relations Review 66 (4), 833-873.

URL http://dx.doi.org/10.1177/001979391306600405

Lotti, F., Santarelli, E., Vivarelli, M., 2009. Defending Gibrat's Law as a long-run regularity. Small Business Economics 32 (1), 31-44.

URL http://dx.doi.org/10.1007/s11187-007-9071-0

McKelvie, A., Brattström, A., Wennberg, K., 2017. How young firms achieve growth: Reconciling the roles of growth motivation and innovative activities. Small Business Economics, 1-21.

Menon, C., DeStefano, T., Manaresi, F., Soggia, G., Santoleri, P., 2018. The evaluation of the Italian Start-up Act. OECD Science, Technology and Industry Policy Papers.

Navaretti, G. B., Castellani, D., Pieri, F., 2014. Age and firm growth: evidence from three European countries. Small Business Economics 43 (4), 823-837.

URL http://dx.doi.org/10.1007/s11187-014-9564-6

Niefert, M., 2007. Effects of patenting behavior on corporate growth: A panel data analysis of German start-up firms. Springer Berlin Heidelberg, pp. 373-390.

URL http://dx.doi.org/10.1007/978-3-540-49465-2_19

Nightingale, P., Coad, A., 12 2013. Muppets and gazelles: political and methodological biases in entrepreneurship research. Industrial and Corporate Change 23 (1), 113-143.

URL https://doi.org/10.1093/icc/dtt057

Ortega-Argilés, R., Vivarelli, M., Voigt, P., 2009. R\&D in SMEs: a paradox? Small Business Economics 33 (1), 3-11. URL http://dx.doi.org/10.1007/s11187-009-9187-5

Ouimet, P., Zarutskie, R., 2014. Who works for startups? The relation between firm age, employee age, and growth. Journal of financial Economics 112 (3), 386-407.

URL http://doi.org/10.1016/j.jfineco.2014.03.003

Pellegrino, G., Piva, M., Vivarelli, M., 2012. Young firms and innovation: A microeconometric analysis. Structural Change and Economic Dynamics 23 (4), 329-340.

Protogerou, A., Caloghirou, Y., Vonortas, N. S., 2017. Determinants of young firms' innovative performance: Empirical evidence from Europe. Research Policy.

Reinganum, J. F., 1983. Uncertain innovation and the persistence of monopoly. The American Economic Review $73(4), 741-748$.

Robb, A., Robinson, D. T., 2017. Testing for racial bias in business credit scores. Small Business Economics, 1-15. Ryder, N. B., 1965. The cohort as a concept in the study of social change. American sociological review, 843-861.

Schoar, A., 2010. The divide between subsistence and transformational entrepreneurship. In: Innovation Policy and the Economy, Volume 10. University of Chicago Press, pp. 57-81.

URL http://dx.doi.org/10.1086/605853 
Schumpeter, J. A., 1934. The theory of economic development: An inquiry into profits, capital, credit, interest, and the business cycle. Vol. 55. Transaction publishers.

Segarra, A., Teruel, M., 2014. High-growth firms and innovation: An empirical analysis for Spanish firms. Small Business Economics 43 (4), 805-821.

URL http://dx.doi.org/10.1007/s11187-014-9563-7

Shane, S., 2009. Why encouraging more people to become entrepreneurs is bad public policy. Small business economics $33(2), 141-149$.

Shefer, D., Frenkel, A., 2005. R\&D, firm size and innovation: An empirical analysis. Technovation 25 (1), $25-32$. URL http://doi.org/10.1016/S0166-4972(03)00152-4

Silva, F., Carreira, C., et al., 2012. Measuring firms' financial constraints: A rough guide. Notas Económicas 36, $23-46$.

URL http://iduc.uc.pt/index.php/notaseconomicas/article/view/3427/2665

Stam, E., Wennberg, K., 2009. The roles of R\&D in new firm growth. Small Business Economics 33 (1), $77-89$. URL http://dx.doi.org/10.1007/s11187-009-9183-9

Sternberg, R., Wennekers, S., 2005. Determinants and effects of new business creation using global entrepreneurship monitor data. Small business economics 24 (3), 193-203.

Van Reenen, J., 1997. Employment and technological innovation: Evidence from UK manufacturing firms. Journal of labor economics, 255-284.

URL http://dx.doi.org/10.1086/209833

Van Roy, V., Vértesy, D., Vivarelli, M., 2018. Technology and employment: Mass unemployment or job creation? empirical evidence from european patenting firms. Research Policy 47 (9), 1762-1776.

Veugelers, R., Schneider, C., 2017. Which IP strategies do young highly innovative firms choose? Small Business Economics, 1-17.

Vivarelli, M., 2014. Innovation, employment and skills in advanced and developing countries: A survey of economic literature. Journal of Economic Issues 48 (1), 123-154. URL http://www.tandfonline.com/doi/abs/10.2753/JEI0021-3624480106

Wooldridge, J. M., 2010. Econometric analysis of cross section and panel data. MIT press.

Zarutskie, R., Yang, T., 2017. How did young firms fare during the Great Recession? Measuring Entrepreneurial Businesses: Current Knowledge and Challenges 75, 253. 


\section{Appendix A}

Survivorship bias has been pointed out as a major drawback in the literature addressing firm growth dynamics (Garnsey et al., 2006). ${ }^{29}$. It refers to the permanent loss of sample members from a longitudinal sample. This generates a potential bias if those firms withdrawing from the original sample are systematically different from those that stay in the sample during the whole time span covered by the survey. In case this happens, the remaining sample, represents a population different from the original one (Cochran, 1977). Without correcting for it, estimates would not generalize back to the original population of firms, but rather, to the subpopulation of surviving firms.

The literature has traditionally addressed this issue using three main methods (Farhat and Robb, 2014). First, surveyors can attempt to limit attrition by tracking every firm through multiple attempts to contact them. KFS surveyors do this and the issue of firms truly disappearing is rather negligible, as just $3 \%$ of firms in the original sample truly vanish from the data set without any explanation. However, the main issue relates to those new firms that surveyors are able to locate and include in the KFS, but whose data are missing because they have ceased operations. By the last year of data, this figure reaches around half of the original sample of new firms. This basically leaves us with two options: a two-stage sample selection model (Heckman, 1977) or its semiparametric version (Wooldridge, 2010). Alternatively, one can exploit complex sample weighting to adjust for systematic sample attrition in each wave of the survey. This procedure entails that weights are recomputed and reassigned to each surviving firm in each subsequent round to ensure that each wave's resulting sample continues to represent the original population from which the original sample was drawn.

Following Litwin and Phan (2013), this articles relies on survey weights rather than the above alternatives for a number of reasons. First, the effective use of a sample selection model requires, among other things, the identification of at least one variable that drives firm survival without having any systematic relationship with the dependent variables of interest, a condition that is generally arduous to satisfy in practice (Wooldridge, 2010). Moreover, since in this case the dependent variable is employment growth, it is not trivial to find a covariate related to survival but with no systematic relationship with growth because the two derive from similar data generating processes. Second, in those cases in which survey designers foresaw the survival issue at the time of survey design, as in the case of the KFS, estimates that rely on weighting and re-weighting with each subsequent survey wave perform better than two-stage estimates on unweighted data (Farhat and Robb, 2014). This occurs since the weights map the sample in each follow-up survey back to represent the original sample from the baseline. In the baseline year, weights are constructed to account for unequal sampling probabilities that derive from intentional oversampling of some businesses and undersampling of others, that is, sample selection bias. Then, with each subsequent

\footnotetext{
${ }^{29}$ This section largely draws upon Litwin and Phan (2013) and Farhat and Robb (2014)
} 
administration of the survey, weights are first adjusted to compensate for nonresponse, meaning attrition, and adjusted once more to ensure the surviving population represents the original one. This means that by employing probability weights, we are not only addressing survival bias: the weights ensure that estimates pertaining to the original sample - which strategically oversampled some firms and undersampled others - also generalize to the intended original population of new businesses. Furthermore, we would want to use survey weights to guarantee generalizability to the entire universe of new firms established in 2004. Therefore, relying on weights works to address sampling bias as well as the larger challenge arising from survival bias. Lastly, incorporating survey design features also enables us to partially relax the usual assumption of conditional independence across all observations, noted above, which would otherwise have to be done by estimating clustered standard errors.

\section{Appendix B}

Table 6: R\&D, patents and employment growth

\begin{tabular}{|c|c|c|c|c|c|c|c|c|c|}
\hline & \multicolumn{9}{|c|}{ Fixed effects quantile regressions } \\
\hline & p10 & p20 & p30 & $\mathrm{p} 40$ & $\mathrm{p} 50$ & p60 & $\mathrm{p} 70$ & $\mathrm{p} 80$ & p90 \\
\hline $\mathrm{R} \& \mathrm{D}_{t-1}$ & $\begin{array}{c}0.024 \\
(0.028)\end{array}$ & $\begin{array}{c}0.025 \\
(0.017)\end{array}$ & $\begin{array}{c}0.028^{* *} \\
(0.013)\end{array}$ & $\begin{array}{c}0.020^{* *} \\
(0.010)\end{array}$ & $\begin{array}{c}0.025^{* * *} \\
(0.007)\end{array}$ & $\begin{array}{c}0.023^{* * *} \\
(0.008)\end{array}$ & $\begin{array}{l}0.028^{*} \\
(0.016)\end{array}$ & $\begin{array}{c}0.058^{* * *} \\
(0.022)\end{array}$ & $\begin{array}{c}0.074^{* * *} \\
(0.026)\end{array}$ \\
\hline $\mathrm{Pat}_{t-1}$ & $\begin{array}{c}0.048^{* *} \\
(0.024)\end{array}$ & $\begin{array}{l}0.045^{*} \\
(0.025)\end{array}$ & $\begin{array}{c}0.063^{* * *} \\
(0.018)\end{array}$ & $\begin{array}{c}0.062^{* * * *} \\
(0.018)\end{array}$ & $\begin{array}{c}0.064^{* * * *} \\
(0.023)\end{array}$ & $\begin{array}{c}0.078^{* * *} \\
(0.025)\end{array}$ & $\begin{array}{c}0.087^{* * *} \\
(0.028)\end{array}$ & $\begin{array}{c}0.104^{* * *} \\
(0.035)\end{array}$ & $\begin{array}{c}0.122^{* * * *} \\
(0.030)\end{array}$ \\
\hline Growth $_{t-1}$ & $\begin{array}{c}0.011 \\
(0.017)\end{array}$ & $\begin{array}{c}-0.007 \\
(0.015)\end{array}$ & $\begin{array}{c}0.005 \\
(0.014)\end{array}$ & $\begin{array}{c}0.006 \\
(0.009)\end{array}$ & $\begin{array}{c}-0.000 \\
(0.009)\end{array}$ & $\begin{array}{c}-0.004 \\
(0.010)\end{array}$ & $\begin{array}{c}-0.007 \\
(0.013)\end{array}$ & $\begin{array}{l}-0.015 \\
(0.016)\end{array}$ & $\begin{array}{c}0.005 \\
(0.020)\end{array}$ \\
\hline $\operatorname{Inv}_{t}$ & $\begin{array}{c}0.016^{* * *} \\
(0.004)\end{array}$ & $\begin{array}{c}0.011^{* * *} \\
(0.003)\end{array}$ & $\begin{array}{l}0.004^{*} \\
(0.003)\end{array}$ & $\begin{array}{c}0.004^{* *} \\
(0.002)\end{array}$ & $\begin{array}{l}0.002^{*} \\
(0.001)\end{array}$ & $\begin{array}{c}0.001 \\
(0.001)\end{array}$ & $\begin{array}{c}0.003 \\
(0.002)\end{array}$ & $\begin{array}{c}0.003 \\
(0.004)\end{array}$ & $\begin{array}{l}-0.001 \\
(0.005)\end{array}$ \\
\hline Credit $_{t-1}$ & $\begin{array}{c}0.002^{* * *} \\
(0.000)\end{array}$ & $\begin{array}{c}0.002^{* * *} \\
(0.000)\end{array}$ & $\begin{array}{c}0.001^{* * *} \\
(0.000)\end{array}$ & $\begin{array}{c}0.001^{* * *} \\
(0.000)\end{array}$ & $\begin{array}{c}0.001^{* * *} \\
(0.000)\end{array}$ & $\begin{array}{c}0.001^{* * *} \\
(0.000)\end{array}$ & $\begin{array}{c}0.001^{* * *} \\
(0.000)\end{array}$ & $\begin{array}{c}0.001^{* * *} \\
(0.000)\end{array}$ & $\begin{array}{c}0.001^{* *} \\
(0.000)\end{array}$ \\
\hline $\operatorname{Size}_{t-1}$ & $\begin{array}{c}-0.926^{* * *} \\
(0.012)\end{array}$ & $\begin{array}{c}-0.926^{* * *} \\
(0.007)\end{array}$ & $\begin{array}{c}-0.927^{* * *} \\
(0.006)\end{array}$ & $\begin{array}{c}-0.931^{* * *} \\
(0.005)\end{array}$ & $\begin{array}{c}-0.920^{* * *} \\
(0.004)\end{array}$ & $\begin{array}{c}-0.908^{* * *} \\
(0.004)\end{array}$ & $\begin{array}{c}-0.896^{* * *} \\
(0.007)\end{array}$ & $\begin{array}{c}-0.921^{* * *} \\
(0.011)\end{array}$ & $\begin{array}{c}-0.972^{* * *} \\
(0.012)\end{array}$ \\
\hline Location $_{t}$ & $\begin{array}{c}0.003 \\
(0.003)\end{array}$ & $\begin{array}{c}0.002 \\
(0.003)\end{array}$ & $\begin{array}{c}0.002 \\
(0.002)\end{array}$ & $\begin{array}{c}0.001 \\
(0.002)\end{array}$ & $\begin{array}{c}0.001 \\
(0.002)\end{array}$ & $\begin{array}{c}0.001 \\
(0.002)\end{array}$ & $\begin{array}{c}0.002 \\
(0.001)\end{array}$ & $\begin{array}{c}0.000 \\
(0.001)\end{array}$ & $\begin{array}{c}-0.000 \\
(0.003)\end{array}$ \\
\hline Constant & $\begin{array}{c}0.693^{* * *} \\
(0.101)\end{array}$ & $\begin{array}{c}0.769^{* * *} \\
(0.062)\end{array}$ & $\begin{array}{c}0.846^{* * *} \\
(0.056)\end{array}$ & $\begin{array}{c}0.816^{* * *} \\
(0.080)\end{array}$ & $\begin{array}{c}0.901^{* * *} \\
(0.160)\end{array}$ & $\begin{array}{c}0.900^{* * *} \\
(0.192)\end{array}$ & $\begin{array}{c}1.028^{* * *} \\
(0.302)\end{array}$ & $\begin{array}{c}1.171^{* * *} \\
(0.331)\end{array}$ & $\begin{array}{c}1.796^{* * *} \\
(0.310)\end{array}$ \\
\hline Firm FE & Yes & Yes & Yes & Yes & Yes & Yes & Yes & Yes & Yes \\
\hline State FE & Yes & Yes & Yes & Yes & Yes & Yes & Yes & Yes & Yes \\
\hline Sector FE & Yes & Yes & Yes & Yes & Yes & Yes & Yes & Yes & Yes \\
\hline Time FE & Yes & Yes & Yes & Yes & Yes & Yes & Yes & Yes & Yes \\
\hline Legal f. FE & Yes & Yes & Yes & Yes & Yes & Yes & Yes & Yes & Yes \\
\hline$N$ & 8127 & 8127 & 8127 & 8127 & 8127 & 8127 & 8127 & 8127 & 8127 \\
\hline Pseudo $R^{2}$ & 0.680 & 0.685 & 0.688 & 0.689 & 0.687 & 0.676 & 0.655 & 0.617 & 0.560 \\
\hline
\end{tabular}

Notes: Fixed Effects QR (Canay, 2011) estimates using KFS survey weights. Bootstrapped standard errors (100 iterations) based on Kolenikov et al. (2010) are in parenthesis. Time (6), sector (21), State (52) and legal forms (6) dummies are included but not reported for the sake of brevity. ${ }^{*} p<0.10,{ }^{* *} p<0.05,{ }^{* * *} p<0.01$. 
Table 7: Principal component analysis of innovation variables

\begin{tabular}{lcccc}
\hline Component & Eigenvalue & Difference & Proportion & Cumulative \\
\hline INN1 & 1.097 & 0.193 & 0.548 & 0.548 \\
INN2 & 0.903 & - & 0.452 & 1.000 \\
& & & & \\
\hline
\end{tabular}

Notes: based on 6045 observations.

Table 8: Innovativeness index and employment growth

\begin{tabular}{|c|c|c|c|c|c|c|c|c|c|}
\hline & \multicolumn{9}{|c|}{ Fixed effects quantile regressions } \\
\hline & p10 & p20 & p30 & $\mathrm{p} 40$ & p50 & p60 & p70 & $\mathrm{p} 80$ & p90 \\
\hline $\mathrm{INN}_{t-1}$ & $\begin{array}{c}0.022 \\
(0.015)\end{array}$ & $\begin{array}{l}0.020^{*} \\
(0.011)\end{array}$ & $\begin{array}{c}0.024^{* * *} \\
(0.007)\end{array}$ & $\begin{array}{c}0.023^{* * *} \\
(0.005)\end{array}$ & $\begin{array}{c}0.026^{* * *} \\
(0.005)\end{array}$ & $\begin{array}{c}0.024^{* * *} \\
(0.006)\end{array}$ & $\begin{array}{c}0.032^{* * * *} \\
(0.009)\end{array}$ & $\begin{array}{c}0.041^{* * *} \\
(0.011)\end{array}$ & $\begin{array}{c}0.046^{* * *} \\
(0.013)\end{array}$ \\
\hline $\operatorname{Growth}_{t-1}$ & $\begin{array}{l}-0.008 \\
(0.027)\end{array}$ & $\begin{array}{c}0.008 \\
(0.019)\end{array}$ & $\begin{array}{c}0.054^{* * *} \\
(0.011)\end{array}$ & $\begin{array}{c}0.047^{* * *} \\
(0.008)\end{array}$ & $\begin{array}{c}0.031^{* * *} \\
(0.007)\end{array}$ & $\begin{array}{c}0.013 \\
(0.008)\end{array}$ & $\begin{array}{c}-0.003 \\
(0.011)\end{array}$ & $\begin{array}{l}-0.005 \\
(0.019)\end{array}$ & $\begin{array}{c}0.022 \\
(0.031)\end{array}$ \\
\hline $\operatorname{Inv}_{t}$ & $\begin{array}{c}0.017^{* * *} \\
(0.005)\end{array}$ & $\begin{array}{c}0.005 \\
(0.004)\end{array}$ & $\begin{array}{c}0.002 \\
(0.004)\end{array}$ & $\begin{array}{c}-0.001 \\
(0.003)\end{array}$ & $\begin{array}{c}0.000 \\
(0.002)\end{array}$ & $\begin{array}{l}-0.000 \\
(0.003)\end{array}$ & $\begin{array}{l}-0.003 \\
(0.004)\end{array}$ & $\begin{array}{l}-0.000 \\
(0.004)\end{array}$ & $\begin{array}{l}-0.003 \\
(0.005)\end{array}$ \\
\hline Credit $_{t-1}$ & $\begin{array}{c}0.002^{* * *} \\
(0.000)\end{array}$ & $\begin{array}{c}0.002^{* * *} \\
(0.000)\end{array}$ & $\begin{array}{c}0.002^{* * *} \\
(0.000)\end{array}$ & $\begin{array}{c}0.002^{* * *} \\
(0.000)\end{array}$ & $\begin{array}{c}0.002^{* * * *} \\
(0.000)\end{array}$ & $\begin{array}{c}0.002^{* * *} \\
(0.000)\end{array}$ & $\begin{array}{c}0.002^{* * *} \\
(0.000)\end{array}$ & $\begin{array}{c}0.001^{* * *} \\
(0.000)\end{array}$ & $\begin{array}{c}0.001^{* * *} \\
(0.000)\end{array}$ \\
\hline Size $_{t-1}$ & $\begin{array}{c}-0.783^{* * *} \\
(0.016)\end{array}$ & $\begin{array}{c}-0.785^{* * *} \\
(0.010)\end{array}$ & $\begin{array}{c}-0.812^{* * *} \\
(0.008)\end{array}$ & $\begin{array}{c}-0.821^{* * *} \\
(0.005)\end{array}$ & $\begin{array}{c}-0.813^{* * *} \\
(0.005)\end{array}$ & $\begin{array}{c}-0.813^{* * *} \\
(0.006)\end{array}$ & $\begin{array}{c}-0.816^{* * *} \\
(0.006)\end{array}$ & $\begin{array}{c}-0.826^{* * *} \\
(0.009)\end{array}$ & $\begin{array}{c}-0.842^{* * *} \\
(0.013)\end{array}$ \\
\hline Location $_{t}$ & $\begin{array}{c}0.019^{* * * *} \\
(0.006)\end{array}$ & $\begin{array}{c}0.016^{* * *} \\
(0.005)\end{array}$ & $\begin{array}{c}0.015^{* *} \\
(0.006)\end{array}$ & $\begin{array}{c}0.024^{* * *} \\
(0.005)\end{array}$ & $\begin{array}{c}0.024^{* * * *} \\
(0.004)\end{array}$ & $\begin{array}{c}0.022^{* * * *} \\
(0.006)\end{array}$ & $\begin{array}{c}0.020^{* * *} \\
(0.007)\end{array}$ & $\begin{array}{c}0.029^{* * * *} \\
(0.010)\end{array}$ & $\begin{array}{c}0.028 \\
(0.017)\end{array}$ \\
\hline Constant & $\begin{array}{c}0.644^{* * *} \\
(0.220)\end{array}$ & $\begin{array}{c}0.791^{* * *} \\
(0.151)\end{array}$ & $\begin{array}{c}1.073^{* * *} \\
(0.112)\end{array}$ & $\begin{array}{c}1.163^{* * *} \\
(0.085)\end{array}$ & $\begin{array}{c}1.273^{* * *} \\
(0.099)\end{array}$ & $\begin{array}{c}1.315^{* * *} \\
(0.105)\end{array}$ & $\begin{array}{c}1.485^{* * *} \\
(0.114)\end{array}$ & $\begin{array}{c}1.720^{* * *} \\
(0.126)\end{array}$ & $\begin{array}{c}1.768^{* * *} \\
(0.142)\end{array}$ \\
\hline Firm FE & Yes & Yes & Yes & Yes & Yes & Yes & Yes & Yes & Yes \\
\hline State FE & Yes & Yes & Yes & Yes & Yes & Yes & Yes & Yes & Yes \\
\hline Sector FE & Yes & Yes & Yes & Yes & Yes & Yes & Yes & Yes & Yes \\
\hline Time FE & Yes & Yes & Yes & Yes & Yes & Yes & Yes & Yes & Yes \\
\hline Legal f. FE & Yes & Yes & Yes & Yes & Yes & Yes & Yes & Yes & Yes \\
\hline$N$ & 6045 & 6045 & 6045 & 6045 & 6045 & 6045 & 6045 & 6045 & 6045 \\
\hline Pseudo $R^{2}$ & 0.600 & 0.605 & 0.606 & 0.606 & 0.599 & 0.582 & 0.559 & 0.531 & 0.486 \\
\hline
\end{tabular}

Notes: Fixed Effects QR (Canay, 2011) estimates using KFS survey weights. Bootstrapped standard errors (100 iterations) based on Kolenikov et al. (2010) are in parenthesis. Time (6), sector (21), State (52) and legal forms (6) dummies are included but not reported for the sake of brevity. ${ }^{*} p<0.10,{ }^{* *} p<0.05,{ }^{* * *} p<0.01$. 
Table 9: R\&D and employment growth (no lagged dep. var.)

\begin{tabular}{|c|c|c|c|c|c|c|c|c|c|}
\hline & \multicolumn{9}{|c|}{ Fixed effects quantile regressions } \\
\hline & $\mathrm{p} 10$ & $\mathrm{p} 20$ & p30 & $\mathrm{p} 40$ & $\mathrm{p} 50$ & $\mathrm{p} 60$ & $\mathrm{p} 70$ & $\mathrm{p} 80$ & p90 \\
\hline $\mathrm{R} \& \mathrm{D}_{t-1}$ & $\begin{array}{c}0.006 \\
(0.026)\end{array}$ & $\begin{array}{c}0.028 \\
(0.020)\end{array}$ & $\begin{array}{c}0.038^{* * *} \\
(0.013)\end{array}$ & $\begin{array}{c}0.029^{* * *} \\
(0.011)\end{array}$ & $\begin{array}{c}0.039^{* * *} \\
(0.008)\end{array}$ & $\begin{array}{c}0.041^{* * *} \\
(0.009)\end{array}$ & $\begin{array}{c}0.065^{* * *} \\
(0.017)\end{array}$ & $\begin{array}{c}0.084^{* * *} \\
(0.018)\end{array}$ & $\begin{array}{c}0.087^{* * *} \\
(0.024)\end{array}$ \\
\hline $\operatorname{Inv}_{t}$ & $\begin{array}{c}0.018^{* * *} \\
(0.005)\end{array}$ & $\begin{array}{l}0.007^{*} \\
(0.004)\end{array}$ & $\begin{array}{c}0.005^{* *} \\
(0.002)\end{array}$ & $\begin{array}{c}0.005^{* *} \\
(0.002)\end{array}$ & $\begin{array}{l}0.002^{*} \\
(0.001)\end{array}$ & $\begin{array}{c}0.001 \\
(0.001)\end{array}$ & $\begin{array}{c}0.003 \\
(0.002)\end{array}$ & $\begin{array}{c}0.004 \\
(0.003)\end{array}$ & $\begin{array}{c}0.002 \\
(0.005)\end{array}$ \\
\hline Credit $_{t-1}$ & $\begin{array}{c}0.002^{* * *} \\
(0.000)\end{array}$ & $\begin{array}{c}0.001^{* * *} \\
(0.000)\end{array}$ & $\begin{array}{c}0.001^{* * *} \\
(0.000)\end{array}$ & $\begin{array}{c}0.001^{* * *} \\
(0.000)\end{array}$ & $\begin{array}{c}0.001^{* * *} \\
(0.000)\end{array}$ & $\begin{array}{c}0.001^{* * *} \\
(0.000)\end{array}$ & $\begin{array}{c}0.001^{* * *} \\
(0.000)\end{array}$ & $\begin{array}{l}0.000^{*} \\
(0.000)\end{array}$ & $\begin{array}{c}0.001 \\
(0.000)\end{array}$ \\
\hline Size $_{t-1}$ & $\begin{array}{c}-0.913^{* * *} \\
(0.014)\end{array}$ & $\begin{array}{c}-0.886^{* * *} \\
(0.007)\end{array}$ & $\begin{array}{c}-0.887^{* * *} \\
(0.005)\end{array}$ & $\begin{array}{c}-0.890^{* * *} \\
(0.005)\end{array}$ & $\begin{array}{c}-0.884^{* * *} \\
(0.004)\end{array}$ & $\begin{array}{c}-0.868^{* * *} \\
(0.004)\end{array}$ & $\begin{array}{c}-0.863^{* * *} \\
(0.007)\end{array}$ & $\begin{array}{c}-0.886^{* * *} \\
(0.009)\end{array}$ & $\begin{array}{c}-0.938^{* * *} \\
(0.012)\end{array}$ \\
\hline Constant & $\begin{array}{c}0.684^{* * *} \\
(0.111)\end{array}$ & $\begin{array}{c}0.783^{* * *} \\
(0.067)\end{array}$ & $\begin{array}{c}0.823^{* * *} \\
(0.059)\end{array}$ & $\begin{array}{c}0.895^{* * *} \\
(0.062)\end{array}$ & $\begin{array}{c}0.870^{* * *} \\
(0.110)\end{array}$ & $\begin{array}{c}0.880^{* * *} \\
(0.116)\end{array}$ & $\begin{array}{c}0.954^{* * *} \\
(0.297)\end{array}$ & $\begin{array}{c}1.065^{* * *} \\
(0.323)\end{array}$ & $\begin{array}{c}1.667^{* * * *} \\
(0.338)\end{array}$ \\
\hline Firm FE & Yes & Yes & Yes & Yes & Yes & Yes & Yes & Yes & Yes \\
\hline State FE & Yes & Yes & Yes & Yes & Yes & Yes & Yes & Yes & Yes \\
\hline Sector FE & Yes & Yes & Yes & Yes & Yes & Yes & Yes & Yes & Yes \\
\hline Time FE & Yes & Yes & Yes & Yes & Yes & Yes & Yes & Yes & Yes \\
\hline Legal f. FE & Yes & Yes & Yes & Yes & Yes & Yes & Yes & Yes & Yes \\
\hline$N$ & 10251 & 10251 & 10251 & 10251 & 10251 & 10251 & 10251 & 10251 & 10251 \\
\hline Pseudo $R^{2}$ & 0.643 & 0.651 & 0.656 & 0.660 & 0.658 & 0.646 & 0.622 & 0.580 & 0.525 \\
\hline
\end{tabular}

Notes: Fixed Effects QR (Canay, 2011) estimates using KFS survey weights. Bootstrapped standard errors (100 iterations) based on Kolenikov et al. (2010) are in parenthesis. Time (7), sector (21), State (52) and legal forms (6) dummies are included but not reported for the sake of brevity. ${ }^{*} p<0.10,{ }^{* *} p<0.05,{ }^{* * *} p<0.01$.

Table 10: Patents and employment growth (no lagged dep. var.)

\begin{tabular}{lccccccccc}
\hline & \multicolumn{7}{c}{ Fixed effects quantile regressions } \\
\cline { 2 - 8 } & $\mathrm{p} 10$ & $\mathrm{p} 20$ & $\mathrm{p} 30$ & $\mathrm{p} 40$ & $\mathrm{p} 50$ & $\mathrm{p} 60$ & $\mathrm{p} 70$ & $\mathrm{p} 80$ & $\mathrm{p} 90$ \\
\hline Pat $t-1$ & 0.050 & $0.098^{* * *}$ & $0.101^{* * *}$ & $0.110^{* * *}$ & $0.110^{* * *}$ & $0.133^{* * *}$ & $0.149^{* * *}$ & $0.154^{* * *}$ & $0.171^{* * *}$ \\
& $(0.045)$ & $(0.026)$ & $(0.025)$ & $(0.020)$ & $(0.020)$ & $(0.021)$ & $(0.018)$ & $(0.027)$ & $(0.041)$ \\
Inv $t$ & $0.016^{* * *}$ & $0.008^{* *}$ & $0.004^{*}$ & $0.004^{*}$ & 0.002 & 0.001 & 0.003 & 0.004 & -0.001 \\
& $(0.005)$ & $(0.004)$ & $(0.002)$ & $(0.002)$ & $(0.001)$ & $(0.001)$ & $(0.002)$ & $(0.003)$ & $(0.004)$ \\
& $0.002^{* * *}$ & $0.001^{* * *}$ & $0.001^{* * *}$ & $0.001^{* * *}$ & $0.001^{* * *}$ & $0.001^{* * *}$ & $0.001^{* * *}$ & $0.001^{* *}$ & $0.001^{* *}$ \\
Credit $t-1$ & $(0.000)$ & $(0.000)$ & $(0.000)$ & $(0.000)$ & $(0.000)$ & $(0.000)$ & $(0.000)$ & $(0.000)$ & $(0.000)$ \\
& $-0.913^{* * *}$ & $-0.886^{* * *}$ & $-0.887^{* * *}$ & $-0.890^{* * *}$ & $-0.885^{* * *}$ & $-0.869^{* * *}$ & $-0.860^{* * *}$ & $-0.887^{* * *}$ & $-0.933^{* * *}$ \\
Size $t-1$ & $(0.014)$ & $(0.007)$ & $(0.005)$ & $(0.004)$ & $(0.004)$ & $(0.004)$ & $(0.006)$ & $(0.009)$ & $(0.011)$ \\
& $0.695^{* * *}$ & $0.772^{* * *}$ & $0.824^{* * *}$ & $0.858^{* * *}$ & $0.878^{* * *}$ & $0.887^{* * *}$ & $0.930^{* * *}$ & $1.007^{* * *}$ & $1.699^{* * *}$ \\
Constant & $(0.111)$ & $(0.063)$ & $(0.056)$ & $(0.062)$ & $(0.111)$ & $(0.110)$ & $(0.298)$ & $(0.332)$ & $(0.348)$ \\
& Yes & Yes & Yes & Yes & Yes & Yes & Yes & Yes & Yes \\
Firm FE & Yes & Yes & Yes & Yes & Yes & Yes & Yes & Yes & Yes \\
State FE & Yes & Yes & Yes & Yes & Yes & Yes & Yes & Yes & Yes \\
Sector FE & Yes & Yes & Yes & Yes & Yes & Yes & Yes & Yes & Yes \\
Time FE & Yes & Yes & Yes & Yes & Yes & Yes & Yes & Yes & Yes \\
Legal f. FE & 10251 & 10251 & 10251 & 10251 & 10251 & 10251 & 10251 & 10251 & 10251 \\
\hline$N$ & 0.643 & 0.651 & 0.656 & 0.660 & 0.658 & 0.646 & 0.623 & 0.580 & 0.524 \\
Pseudo $R^{2}$ & & & & & &
\end{tabular}

Notes: Fixed Effects QR (Canay, 2011) estimates using KFS survey weights. Bootstrapped standard errors (100 iterations) based on Kolenikov et al. (2010) are in parenthesis. Time (7), sector (21), State (52) and legal forms (6) dummies are included but not reported for the sake of brevity. ${ }^{*} p<0.10,{ }^{* *} p<0.05,{ }^{* * *} p<0.01$. 
Table 11: R\&D intensity and employment growth

\begin{tabular}{|c|c|c|c|c|c|c|c|c|c|}
\hline & \multicolumn{9}{|c|}{ Fixed effects quantile regressions } \\
\hline & p10 & $\mathrm{p} 20$ & p30 & $\mathrm{p} 40$ & p50 & $\mathrm{p} 60$ & p70 & $\mathrm{p} 80$ & p90 \\
\hline${\mathrm{R} \& \operatorname{Dint}_{t-1}}$ & $\begin{array}{c}0.018 \\
(0.072)\end{array}$ & $\begin{array}{c}0.022 \\
(0.058)\end{array}$ & $\begin{array}{c}0.045 \\
(0.045)\end{array}$ & $\begin{array}{c}0.074^{* * *} \\
(0.024)\end{array}$ & $\begin{array}{c}0.086^{* * *} \\
(0.018)\end{array}$ & $\begin{array}{c}0.106^{* * *} \\
(0.023)\end{array}$ & $\begin{array}{c}0.135^{* * *} \\
(0.030)\end{array}$ & $\begin{array}{c}0.156^{* * *} \\
(0.052)\end{array}$ & $\begin{array}{c}0.163^{* *} \\
(0.067)\end{array}$ \\
\hline Growth $_{t-1}$ & $\begin{array}{l}-0.010 \\
(0.021)\end{array}$ & $\begin{array}{c}0.006 \\
(0.019)\end{array}$ & $\begin{array}{c}0.037^{* *} \\
(0.015)\end{array}$ & $\begin{array}{c}0.030^{* * * *} \\
(0.010)\end{array}$ & $\begin{array}{c}0.019^{* * *} \\
(0.006)\end{array}$ & $\begin{array}{c}0.003 \\
(0.009)\end{array}$ & $\begin{array}{l}-0.004 \\
(0.012)\end{array}$ & $\begin{array}{c}-0.008 \\
(0.020)\end{array}$ & $\begin{array}{c}0.016 \\
(0.022)\end{array}$ \\
\hline $\operatorname{Inv}_{t}$ & $\begin{array}{c}0.017^{* * *} \\
(0.006)\end{array}$ & $\begin{array}{c}0.005 \\
(0.005)\end{array}$ & $\begin{array}{c}0.002 \\
(0.003)\end{array}$ & $\begin{array}{l}-0.002 \\
(0.003)\end{array}$ & $\begin{array}{l}-0.002 \\
(0.002)\end{array}$ & $\begin{array}{l}-0.003 \\
(0.003)\end{array}$ & $\begin{array}{l}-0.002 \\
(0.003)\end{array}$ & $\begin{array}{l}-0.002 \\
(0.003)\end{array}$ & $\begin{array}{c}-0.004 \\
(0.006)\end{array}$ \\
\hline Credit $_{t-1}$ & $\begin{array}{c}0.002^{* * *} \\
(0.000)\end{array}$ & $\begin{array}{c}0.002^{* * *} \\
(0.000)\end{array}$ & $\begin{array}{c}0.002^{* * *} \\
(0.000)\end{array}$ & $\begin{array}{c}0.002^{* * *} \\
(0.000)\end{array}$ & $\begin{array}{c}0.002^{* * *} \\
(0.000)\end{array}$ & $\begin{array}{c}0.002^{* * *} \\
(0.000)\end{array}$ & $\begin{array}{c}0.002^{* * *} \\
(0.000)\end{array}$ & $\begin{array}{c}0.001^{* * *} \\
(0.000)\end{array}$ & $\begin{array}{c}0.001^{* * *} \\
(0.000)\end{array}$ \\
\hline $\operatorname{Size}_{t-1}$ & $\begin{array}{c}-0.845^{* * *} \\
(0.015)\end{array}$ & $\begin{array}{c}-0.860^{* * *} \\
(0.011)\end{array}$ & $\begin{array}{c}-0.875^{* * *} \\
(0.007)\end{array}$ & $\begin{array}{c}-0.879^{* * *} \\
(0.004)\end{array}$ & $\begin{array}{c}-0.876^{* * *} \\
(0.004)\end{array}$ & $\begin{array}{c}-0.866^{* * *} \\
(0.006)\end{array}$ & $\begin{array}{c}-0.864^{* * *} \\
(0.008)\end{array}$ & $\begin{array}{c}-0.884^{* * *} \\
(0.011)\end{array}$ & $\begin{array}{c}-0.923^{* * *} \\
(0.016)\end{array}$ \\
\hline Location $_{t}$ & $\begin{array}{c}0.018^{* * *} \\
(0.006)\end{array}$ & $\begin{array}{c}0.016^{* * *} \\
(0.005)\end{array}$ & $\begin{array}{c}0.021^{* * *} \\
(0.008)\end{array}$ & $\begin{array}{c}0.027^{* * *} \\
(0.006)\end{array}$ & $\begin{array}{c}0.027^{* * *} \\
(0.003)\end{array}$ & $\begin{array}{c}0.026^{* * *} \\
(0.003)\end{array}$ & $\begin{array}{c}0.023^{* * *} \\
(0.005)\end{array}$ & $\begin{array}{c}0.031^{* * *} \\
(0.009)\end{array}$ & $\begin{array}{l}0.034^{*} \\
(0.021)\end{array}$ \\
\hline Constant & $\begin{array}{c}0.689^{* * *} \\
(0.185)\end{array}$ & $\begin{array}{c}0.950^{* * *} \\
(0.123)\end{array}$ & $\begin{array}{c}1.064^{* * *} \\
(0.120)\end{array}$ & $\begin{array}{c}1.193^{* * *} \\
(0.083)\end{array}$ & $\begin{array}{c}1.239^{* * *} \\
(0.075)\end{array}$ & $\begin{array}{c}1.297^{* * *} \\
(0.065)\end{array}$ & $\begin{array}{c}1.434^{* * *} \\
(0.071)\end{array}$ & $\begin{array}{c}1.526^{* * *} \\
(0.090)\end{array}$ & $\begin{array}{c}1.728^{* * *} \\
(0.131)\end{array}$ \\
\hline Firm FE & Yes & Yes & Yes & Yes & Yes & Yes & Yes & Yes & Yes \\
\hline State FE & Yes & Yes & Yes & Yes & Yes & Yes & Yes & Yes & Yes \\
\hline Sector FE & Yes & Yes & Yes & Yes & Yes & Yes & Yes & Yes & Yes \\
\hline Time FE & Yes & Yes & Yes & Yes & Yes & Yes & Yes & Yes & Yes \\
\hline Legal f. FE & Yes & Yes & Yes & Yes & Yes & Yes & Yes & Yes & Yes \\
\hline$N$ & 6045 & 6045 & 6045 & 6045 & 6045 & 6045 & 6045 & 6045 & 6045 \\
\hline Pseudo $R^{2}$ & 0.630 & 0.639 & 0.643 & 0.647 & 0.646 & 0.637 & 0.626 & 0.615 & 0.598 \\
\hline
\end{tabular}

Notes: Fixed Effects QR (Canay, 2011) estimates using KFS survey weights. Bootstrapped standard errors (100 iterations) based on Kolenikov et al. (2010) are in parenthesis. Time (7), sector (21), State (52) and legal forms (6) dummies are included but not reported for the sake of brevity. ${ }^{*} p<0.10,{ }^{* *} p<0.05,{ }^{* * *} p<0.01$.

Table 12: Intellectual property rights and employment growth

\begin{tabular}{|c|c|c|c|c|c|c|c|c|c|}
\hline & \multicolumn{9}{|c|}{ Fixed effects quantile regressions } \\
\hline & p10 & p20 & p30 & $\mathrm{p} 40$ & $\mathrm{p} 50$ & $\mathrm{p} 60$ & p70 & $\mathrm{p} 80$ & p90 \\
\hline $\mathrm{IP}_{t-1}$ & $\begin{array}{c}0.020 \\
(0.012)\end{array}$ & $\begin{array}{l}0.018^{*} \\
(0.010)\end{array}$ & $\begin{array}{c}0.020^{* * *} \\
(0.006)\end{array}$ & $\begin{array}{c}0.015^{* *} \\
(0.006)\end{array}$ & $\begin{array}{c}0.018^{* * *} \\
(0.004)\end{array}$ & $\begin{array}{c}0.018^{* * *} \\
(0.005)\end{array}$ & $\begin{array}{c}0.026^{* * *} \\
(0.007)\end{array}$ & $\begin{array}{c}0.024^{* * *} \\
(0.008)\end{array}$ & $\begin{array}{c}0.032^{* * *} \\
(0.011)\end{array}$ \\
\hline Growth $_{t-1}$ & $\begin{array}{c}0.006 \\
(0.019)\end{array}$ & $\begin{array}{l}-0.006 \\
(0.014)\end{array}$ & $\begin{array}{c}0.003 \\
(0.013)\end{array}$ & $\begin{array}{c}0.004 \\
(0.010)\end{array}$ & $\begin{array}{c}0.004 \\
(0.009)\end{array}$ & $\begin{array}{l}-0.000 \\
(0.010)\end{array}$ & $\begin{array}{c}-0.006 \\
(0.012)\end{array}$ & $\begin{array}{c}-0.006 \\
(0.016)\end{array}$ & $\begin{array}{c}0.016 \\
(0.018)\end{array}$ \\
\hline $\operatorname{Inv}_{t}$ & $\begin{array}{c}0.017^{* * *} \\
(0.005)\end{array}$ & $\begin{array}{c}0.009^{* * *} \\
(0.003)\end{array}$ & $\begin{array}{c}0.003 \\
(0.002)\end{array}$ & $\begin{array}{c}0.003 \\
(0.002)\end{array}$ & $\begin{array}{c}0.002 \\
(0.001)\end{array}$ & $\begin{array}{c}0.001 \\
(0.002)\end{array}$ & $\begin{array}{c}0.002 \\
(0.002)\end{array}$ & $\begin{array}{c}0.002 \\
(0.004)\end{array}$ & $\begin{array}{c}0.001 \\
(0.004)\end{array}$ \\
\hline Credit $_{t-1}$ & $\begin{array}{c}0.002^{* * *} \\
(0.000)\end{array}$ & $\begin{array}{c}0.002^{* * *} \\
(0.000)\end{array}$ & $\begin{array}{c}0.001^{* * *} \\
(0.000)\end{array}$ & $\begin{array}{c}0.001^{* * *} \\
(0.000)\end{array}$ & $\begin{array}{c}0.001^{* * *} \\
(0.000)\end{array}$ & $\begin{array}{c}0.001^{* * *} \\
(0.000)\end{array}$ & $\begin{array}{c}0.001^{* * *} \\
(0.000)\end{array}$ & $\begin{array}{c}0.001^{* * *} \\
(0.000)\end{array}$ & $\begin{array}{c}0.001^{* * * *} \\
(0.000)\end{array}$ \\
\hline Size $_{t-1}$ & $\begin{array}{c}-0.929^{* * *} \\
(0.013)\end{array}$ & $\begin{array}{c}-0.928^{* * *} \\
(0.008)\end{array}$ & $\begin{array}{c}-0.929^{* * *} \\
(0.006)\end{array}$ & $\begin{array}{c}-0.929^{* * *} \\
(0.004)\end{array}$ & $\begin{array}{c}-0.921^{* * *} \\
(0.004)\end{array}$ & $\begin{array}{c}-0.908^{* * *} \\
(0.004)\end{array}$ & $\begin{array}{c}-0.897^{* * *} \\
(0.006)\end{array}$ & $\begin{array}{c}-0.925^{* * *} \\
(0.010)\end{array}$ & $\begin{array}{c}-0.976^{* * *} \\
(0.012)\end{array}$ \\
\hline Location $_{t}$ & $\begin{array}{c}0.003 \\
(0.002)\end{array}$ & $\begin{array}{c}0.002 \\
(0.002)\end{array}$ & $\begin{array}{c}0.002 \\
(0.002)\end{array}$ & $\begin{array}{c}0.001 \\
(0.002)\end{array}$ & $\begin{array}{c}0.001 \\
(0.002)\end{array}$ & $\begin{array}{c}0.001 \\
(0.002)\end{array}$ & $\begin{array}{c}0.001 \\
(0.002)\end{array}$ & $\begin{array}{c}0.000 \\
(0.001)\end{array}$ & $\begin{array}{c}-0.000 \\
(0.003)\end{array}$ \\
\hline Constant & $\begin{array}{c}0.729^{* * *} \\
(0.104)\end{array}$ & $\begin{array}{c}0.744^{* * *} \\
(0.063)\end{array}$ & $\begin{array}{c}0.810^{* * *} \\
(0.057)\end{array}$ & $\begin{array}{c}0.780^{* * *} \\
(0.090)\end{array}$ & $\begin{array}{c}0.914^{* * *} \\
(0.169)\end{array}$ & $\begin{array}{c}0.936^{* * *} \\
(0.192)\end{array}$ & $\begin{array}{c}1.038^{* * *} \\
(0.302)\end{array}$ & $\begin{array}{c}1.165^{* * *} \\
(0.334)\end{array}$ & $\begin{array}{c}1.782^{* * *} \\
(0.326)\end{array}$ \\
\hline Firm FE & Yes & Yes & Yes & Yes & Yes & Yes & Yes & Yes & Yes \\
\hline State FE & Yes & Yes & Yes & Yes & Yes & Yes & Yes & Yes & Yes \\
\hline Sector FE & Yes & Yes & Yes & Yes & Yes & Yes & Yes & Yes & Yes \\
\hline Time FE & Yes & Yes & Yes & Yes & Yes & Yes & Yes & Yes & Yes \\
\hline Legal f. FE & Yes & Yes & Yes & Yes & Yes & Yes & Yes & Yes & Yes \\
\hline$N$ & 7876 & 7876 & 7876 & 7876 & 7876 & 7876 & 7876 & 7876 & 7876 \\
\hline Pseudo $R^{2}$ & 0.681 & 0.688 & 0.691 & 0.692 & 0.690 & 0.679 & 0.659 & 0.620 & 0.560 \\
\hline
\end{tabular}

Notes: Fixed Effects QR (Canay, 2011) estimates using KFS survey weights. Bootstrapped standard errors (100 iterations) based on Kolenikov et al. (2010) are in parenthesis. Time (7), sector (21), State (52) and legal forms (6) dummies are included but not reported for the sake of brevity. ${ }^{*} p<0.10,{ }^{* *} p<0.05,{ }^{* * *} p<0.01$. 
Table 13: Alternative innovativeness index and employment growth

\begin{tabular}{|c|c|c|c|c|c|c|c|c|c|}
\hline & \multicolumn{9}{|c|}{ Fixed effects quantile regressions } \\
\hline & p10 & p20 & p30 & $\mathrm{p} 40$ & p50 & $\mathrm{p} 60$ & p70 & $\mathrm{p} 80$ & p90 \\
\hline $\mathrm{INN}_{t-1}$ & $\begin{array}{c}0.014 \\
(0.013)\end{array}$ & $\begin{array}{c}0.015 \\
(0.010)\end{array}$ & $\begin{array}{c}0.022^{* * *} \\
(0.008)\end{array}$ & $\begin{array}{c}0.022^{* * *} \\
(0.005)\end{array}$ & $\begin{array}{c}0.024^{* * *} \\
(0.004)\end{array}$ & $\begin{array}{c}0.024^{* * *} \\
(0.006)\end{array}$ & $\begin{array}{c}0.028^{* * *} \\
(0.006)\end{array}$ & $\begin{array}{c}0.030^{* * *} \\
(0.010)\end{array}$ & $\begin{array}{c}0.039^{* * *} \\
(0.015)\end{array}$ \\
\hline Growth $_{t-1}$ & $\begin{array}{c}0.004 \\
(0.026)\end{array}$ & $\begin{array}{c}0.010 \\
(0.018)\end{array}$ & $\begin{array}{c}0.058^{* * *} \\
(0.012)\end{array}$ & $\begin{array}{c}0.048^{* * *} \\
(0.007)\end{array}$ & $\begin{array}{c}0.033^{* * *} \\
(0.007)\end{array}$ & $\begin{array}{c}0.012 \\
(0.008)\end{array}$ & $\begin{array}{c}0.000 \\
(0.011)\end{array}$ & $\begin{array}{l}-0.004 \\
(0.017)\end{array}$ & $\begin{array}{c}0.021 \\
(0.025)\end{array}$ \\
\hline $\operatorname{Inv}_{t}$ & $\begin{array}{c}0.017^{* * * *} \\
(0.006)\end{array}$ & $\begin{array}{c}0.006 \\
(0.005)\end{array}$ & $\begin{array}{c}0.002 \\
(0.003)\end{array}$ & $\begin{array}{c}0.000 \\
(0.002)\end{array}$ & $\begin{array}{c}0.002 \\
(0.002)\end{array}$ & $\begin{array}{c}0.001 \\
(0.003)\end{array}$ & $\begin{array}{l}-0.001 \\
(0.004)\end{array}$ & $\begin{array}{c}0.002 \\
(0.004)\end{array}$ & $\begin{array}{c}0.003 \\
(0.004)\end{array}$ \\
\hline Credit $_{t-1}$ & $\begin{array}{c}0.002^{* * *} \\
(0.000)\end{array}$ & $\begin{array}{c}0.002^{* * *} \\
(0.000)\end{array}$ & $\begin{array}{c}0.002^{* * *} \\
(0.000)\end{array}$ & $\begin{array}{c}0.002^{* * *} \\
(0.000)\end{array}$ & $\begin{array}{c}0.002^{* * *} \\
(0.000)\end{array}$ & $\begin{array}{c}0.002^{* * *} \\
(0.000)\end{array}$ & $\begin{array}{c}0.002^{* * *} \\
(0.000)\end{array}$ & $\begin{array}{c}0.001^{* * *} \\
(0.000)\end{array}$ & $\begin{array}{c}0.001^{* * *} \\
(0.000)\end{array}$ \\
\hline Size $_{t-1}$ & $\begin{array}{c}-0.776^{* * *} \\
(0.016)\end{array}$ & $\begin{array}{c}-0.786^{* * *} \\
(0.011)\end{array}$ & $\begin{array}{c}-0.813^{* * *} \\
(0.008)\end{array}$ & $\begin{array}{c}-0.817^{* * *} \\
(0.005)\end{array}$ & $\begin{array}{c}-0.811^{* * *} \\
(0.005)\end{array}$ & $\begin{array}{c}-0.805^{* * *} \\
(0.006)\end{array}$ & $\begin{array}{c}-0.810^{* * *} \\
(0.007)\end{array}$ & $\begin{array}{c}-0.820^{* * *} \\
(0.009)\end{array}$ & $\begin{array}{c}-0.835^{* * *} \\
(0.013)\end{array}$ \\
\hline Location $_{t}$ & $\begin{array}{c}0.018^{* * *} \\
(0.005)\end{array}$ & $\begin{array}{c}0.016^{* * *} \\
(0.005)\end{array}$ & $\begin{array}{c}0.018^{* * *} \\
(0.006)\end{array}$ & $\begin{array}{c}0.024^{* * *} \\
(0.006)\end{array}$ & $\begin{array}{c}0.024^{* * *} \\
(0.004)\end{array}$ & $\begin{array}{c}0.023^{* * *} \\
(0.005)\end{array}$ & $\begin{array}{c}0.020^{* * *} \\
(0.007)\end{array}$ & $\begin{array}{c}0.029^{* * *} \\
(0.010)\end{array}$ & $\begin{array}{c}0.022 \\
(0.017)\end{array}$ \\
\hline Constant & $\begin{array}{c}0.627^{* * *} \\
(0.221)\end{array}$ & $\begin{array}{c}0.776^{* * *} \\
(0.161)\end{array}$ & $\begin{array}{c}1.075^{* * *} \\
(0.121)\end{array}$ & $\begin{array}{c}1.168^{* * *} \\
(0.092)\end{array}$ & $\begin{array}{c}1.255^{* * *} \\
(0.107)\end{array}$ & $\begin{array}{c}1.311^{* * *} \\
(0.111)\end{array}$ & $\begin{array}{c}1.462^{* * *} \\
(0.119)\end{array}$ & $\begin{array}{c}1.720^{* * *} \\
(0.129)\end{array}$ & $\begin{array}{c}1.742^{* * *} \\
(0.144)\end{array}$ \\
\hline Firm FE & Yes & Yes & Yes & Yes & Yes & Yes & Yes & Yes & Yes \\
\hline State FE & Yes & Yes & Yes & Yes & Yes & Yes & Yes & Yes & Yes \\
\hline Sector FE & Yes & Yes & Yes & Yes & Yes & Yes & Yes & Yes & Yes \\
\hline Time FE & Yes & Yes & Yes & Yes & Yes & Yes & Yes & Yes & Yes \\
\hline Legal f. FE & Yes & Yes & Yes & Yes & Yes & Yes & Yes & Yes & Yes \\
\hline$N$ & 6045 & 6045 & 6045 & 6045 & 6045 & 6045 & 6045 & 6045 & 6045 \\
\hline Pseudo $R^{2}$ & 0.602 & 0.607 & 0.608 & 0.609 & 0.602 & 0.585 & 0.562 & 0.533 & 0.486 \\
\hline
\end{tabular}

Notes: Fixed Effects QR (Canay, 2011) estimates using KFS survey weights. Bootstrapped standard errors (100 iterations) based on Kolenikov et al. (2010) are in parenthesis. Time (7), sector (21), State (52) and legal forms (6) dummies are included but not reported for the sake of brevity. ${ }^{*} p<0.10,{ }^{* *} p<0.05,{ }^{* * *} p<0.01$.

Table 14: R\&D and employment growth

\begin{tabular}{|c|c|c|c|c|c|c|c|c|c|}
\hline & \multicolumn{9}{|c|}{ Cross-sectional quantile regressions } \\
\hline & p10 & p20 & p30 & $\mathrm{p} 40$ & p50 & p60 & p70 & $\mathrm{p} 80$ & p90 \\
\hline $\mathrm{R} \& \mathrm{D}_{t-1}$ & $\begin{array}{l}-0.002 \\
(0.041)\end{array}$ & $\begin{array}{l}-0.006 \\
(0.027)\end{array}$ & $\begin{array}{c}0.017 \\
(0.017)\end{array}$ & $\begin{array}{c}0.009 \\
(0.007)\end{array}$ & $\begin{array}{l}-0.000 \\
(0.002)\end{array}$ & $\begin{array}{l}-0.000 \\
(0.010)\end{array}$ & $\begin{array}{c}0.059^{* * *} \\
(0.022)\end{array}$ & $\begin{array}{c}0.078^{* * *} \\
(0.027)\end{array}$ & $\begin{array}{c}0.086^{* * *} \\
(0.031)\end{array}$ \\
\hline Growth $_{t-1}$ & $\begin{array}{c}-0.360^{* * *} \\
(0.029)\end{array}$ & $\begin{array}{c}-0.312^{* * *} \\
(0.034)\end{array}$ & $\begin{array}{c}-0.191^{* * *} \\
(0.024)\end{array}$ & $\begin{array}{c}-0.122^{* * *} \\
(0.028)\end{array}$ & $\begin{array}{c}0.000 \\
(0.034)\end{array}$ & $\begin{array}{c}0.000 \\
(0.059)\end{array}$ & $\begin{array}{c}-0.237^{* * *} \\
(0.024)\end{array}$ & $\begin{array}{c}-0.257^{* * *} \\
(0.021)\end{array}$ & $\begin{array}{c}-0.206^{* * *} \\
(0.027)\end{array}$ \\
\hline $\operatorname{Inv} t$ & $\begin{array}{c}0.022^{* * *} \\
(0.007)\end{array}$ & $\begin{array}{c}0.013^{* *} \\
(0.006)\end{array}$ & $\begin{array}{l}0.006^{*} \\
(0.003)\end{array}$ & $\begin{array}{c}0.002 \\
(0.001)\end{array}$ & $\begin{array}{c}0.000 \\
(0.000)\end{array}$ & $\begin{array}{c}0.000 \\
(0.001)\end{array}$ & $\begin{array}{c}0.003 \\
(0.003)\end{array}$ & $\begin{array}{c}0.004 \\
(0.005)\end{array}$ & $\begin{array}{c}0.005 \\
(0.007)\end{array}$ \\
\hline Credit $_{t-1}$ & $\begin{array}{c}0.002^{* * *} \\
(0.001)\end{array}$ & $\begin{array}{c}0.002^{* * *} \\
(0.000)\end{array}$ & $\begin{array}{c}0.001^{* * *} \\
(0.000)\end{array}$ & $\begin{array}{c}0.000^{* * *} \\
(0.000)\end{array}$ & $\begin{array}{l}-0.000 \\
(0.000)\end{array}$ & $\begin{array}{c}0.000 \\
(0.000)\end{array}$ & $\begin{array}{c}0.001^{* * *} \\
(0.000)\end{array}$ & $\begin{array}{l}0.001^{*} \\
(0.000)\end{array}$ & $\begin{array}{c}0.000 \\
(0.000)\end{array}$ \\
\hline Size $_{t-1}$ & $\begin{array}{c}-0.144^{* * *} \\
(0.023)\end{array}$ & $\begin{array}{c}-0.077^{* * *} \\
(0.015)\end{array}$ & $\begin{array}{c}-0.070^{* * *} \\
(0.006)\end{array}$ & $\begin{array}{c}-0.034^{* * *} \\
(0.005)\end{array}$ & $\begin{array}{l}-0.000 \\
(0.004)\end{array}$ & $\begin{array}{c}0.000 \\
(0.003)\end{array}$ & $\begin{array}{l}-0.015 \\
(0.010)\end{array}$ & $\begin{array}{c}-0.100^{* * *} \\
(0.014)\end{array}$ & $\begin{array}{c}-0.175^{* * *} \\
(0.015)\end{array}$ \\
\hline Location $_{t}$ & $\begin{array}{c}0.002 \\
(0.003)\end{array}$ & $\begin{array}{c}0.001 \\
(0.003)\end{array}$ & $\begin{array}{c}0.000 \\
(0.002)\end{array}$ & $\begin{array}{c}0.000 \\
(0.001)\end{array}$ & $\begin{array}{c}0.000 \\
(0.001)\end{array}$ & $\begin{array}{c}0.000 \\
(0.002)\end{array}$ & $\begin{array}{c}0.001 \\
(0.004)\end{array}$ & $\begin{array}{c}0.004 \\
(0.004)\end{array}$ & $\begin{array}{c}0.007 \\
(0.016)\end{array}$ \\
\hline Constant & $\begin{array}{c}-0.437^{* * *} \\
(0.164)\end{array}$ & $\begin{array}{l}-0.199 \\
(0.159)\end{array}$ & $\begin{array}{l}-0.135 \\
(0.170)\end{array}$ & $\begin{array}{l}-0.089 \\
(0.176)\end{array}$ & $\begin{array}{c}0.000 \\
(0.216)\end{array}$ & $\begin{array}{l}-0.000 \\
(0.227)\end{array}$ & $\begin{array}{c}0.218 \\
(0.359)\end{array}$ & $\begin{array}{c}0.276 \\
(0.391)\end{array}$ & $\begin{array}{c}1.012^{* * *} \\
(0.367)\end{array}$ \\
\hline Firm FE & No & No & No & No & No & No & No & No & No \\
\hline State FE & Yes & Yes & Yes & Yes & Yes & Yes & Yes & Yes & Yes \\
\hline Sector FE & Yes & Yes & Yes & Yes & Yes & Yes & Yes & Yes & Yes \\
\hline Time FE & Yes & Yes & Yes & Yes & Yes & Yes & Yes & Yes & Yes \\
\hline Legal f. FE & Yes & Yes & Yes & Yes & Yes & Yes & Yes & Yes & Yes \\
\hline$N$ & 8127 & 8127 & 8127 & 8127 & 8127 & 8127 & 8127 & 8127 & 8127 \\
\hline Pseudo $R^{2}$ & 0.147 & 0.119 & 0.065 & 0.010 & 0.001 & 0.002 & 0.047 & 0.100 & 0.145 \\
\hline
\end{tabular}

Notes: Cross-sectional QR (Koenker and Bassett Jr, 1978) estimates using KFS survey weights. Bootstrapped standard errors (100 iterations) based on Kolenikov et al. (2010) are in parenthesis. Time (6), sector (21), State (52) and legal forms (6) dummies are included but not reported for the sake of brevity. ${ }^{*} p<0.10,{ }^{* *} p<0.05,{ }^{* * *} p<0.01$. 
Table 15: Patents and employment growth

\begin{tabular}{|c|c|c|c|c|c|c|c|c|c|}
\hline & \multicolumn{9}{|c|}{ Cross-sectional quantile regressions } \\
\hline & p10 & p20 & p30 & $\mathrm{p} 40$ & p50 & p60 & p70 & p80 & p90 \\
\hline \multirow{2}{*}{ Pat $_{t-1}$} & -0.042 & -0.050 & 0.007 & -0.010 & 0.000 & 0.000 & 0.017 & $0.086^{* *}$ & $0.127^{* *}$ \\
\hline & $(0.093)$ & $(0.044)$ & $(0.029)$ & $(0.015)$ & $(0.005)$ & $(0.015)$ & $(0.028)$ & $(0.036)$ & $(0.053)$ \\
\hline \multirow{2}{*}{ Growth $_{t-1}$} & $-0.364^{* * *}$ & $-0.312^{* * *}$ & $-0.193^{* * *}$ & $-0.121^{* * *}$ & 0.000 & 0.000 & $-0.238^{* * *}$ & $-0.263^{* * *}$ & $-0.205^{* * *}$ \\
\hline & $(0.029)$ & $(0.034)$ & $(0.025)$ & $(0.029)$ & $(0.034)$ & $(0.058)$ & $(0.024)$ & $(0.021)$ & $(0.026)$ \\
\hline \multirow[t]{2}{*}{$\operatorname{Inv}_{t}$} & $0.021^{* * *}$ & $0.013^{* *}$ & $0.006^{*}$ & 0.002 & 0.000 & -0.000 & 0.003 & 0.003 & 0.003 \\
\hline & $(0.007)$ & $(0.005)$ & $(0.003)$ & $(0.001)$ & $(0.000)$ & $(0.000)$ & $(0.003)$ & $(0.005)$ & $(0.007)$ \\
\hline \multirow[t]{2}{*}{ Credit $_{t-1}$} & $0.002^{* * *}$ & $0.002^{* * *}$ & $0.001^{* * *}$ & $0.000^{* * *}$ & 0.000 & -0.000 & $0.001^{* * *}$ & $0.001^{*}$ & -0.000 \\
\hline & $(0.001)$ & $(0.000)$ & $(0.000)$ & $(0.000)$ & $(0.000)$ & $(0.000)$ & $(0.000)$ & $(0.000)$ & $(0.000)$ \\
\hline \multirow{2}{*}{$\operatorname{Size}_{t-1}$} & $-0.141^{* * *}$ & $-0.078^{* * *}$ & $-0.070^{* * *}$ & $-0.034^{* * *}$ & 0.000 & -0.000 & -0.014 & $-0.094^{* * *}$ & $-0.173^{* * *}$ \\
\hline & $(0.025)$ & $(0.015)$ & $(0.007)$ & $(0.005)$ & $(0.004)$ & $(0.002)$ & $(0.010)$ & $(0.014)$ & $(0.015)$ \\
\hline \multirow[t]{2}{*}{ Location $_{t}$} & 0.002 & 0.001 & 0.000 & 0.000 & 0.000 & 0.000 & 0.001 & 0.004 & 0.008 \\
\hline & $(0.003)$ & $(0.003)$ & $(0.002)$ & $(0.001)$ & $(0.001)$ & $(0.002)$ & $(0.004)$ & $(0.004)$ & $(0.016)$ \\
\hline \multirow[t]{2}{*}{ Constant } & $-0.431^{* * *}$ & -0.191 & -0.129 & -0.087 & 0.000 & -0.000 & 0.224 & 0.271 & $0.956^{* * *}$ \\
\hline & $(0.163)$ & $(0.157)$ & $(0.171)$ & $(0.176)$ & $(0.216)$ & $(0.224)$ & $(0.360)$ & $(0.392)$ & $(0.346)$ \\
\hline Firm FE & No & No & No & No & No & No & No & No & No \\
\hline State FE & Yes & Yes & Yes & Yes & Yes & Yes & Yes & Yes & Yes \\
\hline Sector FE & Yes & Yes & Yes & Yes & Yes & Yes & Yes & Yes & Yes \\
\hline Time FE & Yes & Yes & Yes & Yes & Yes & Yes & Yes & Yes & Yes \\
\hline Legal f. FE & Yes & Yes & Yes & Yes & Yes & Yes & Yes & Yes & Yes \\
\hline$N$ & 8127 & 8127 & 8127 & 8127 & 8127 & 8127 & 8127 & 8127 & 8127 \\
\hline Pseudo $R^{2}$ & 0.147 & 0.119 & 0.065 & 0.010 & 0.001 & 0.002 & 0.046 & 0.099 & 0.144 \\
\hline
\end{tabular}

Notes: Cross-sectional QR (Koenker and Bassett Jr, 1978) estimates using KFS survey weights. Bootstrapped standard errors (100 iterations) based on Kolenikov et al. (2010) are in parenthesis. Time (6), sector (21), State (52) and legal forms (6) dummies are included but not reported for the sake of brevity. ${ }^{*} p<0.10,{ }^{* *} p<0.05,{ }^{* * *} p<0.01$. 